\title{
Etymologisesti hämäriä -(is)tA-johdosverbejä, lainoja ja omapohjaisia
}

Suomessa on paljon verbejä, joiden vartalo päättyy elementtiin -ta-/-tä-. Valtaosa on nomineista johdettuja ns. supistumaverbejä, joissa infinitiivin tunnus on alun perin liittynyt johtimen konsonanttivartaloon; johtimen edellä ollut nominin loppuvokaali

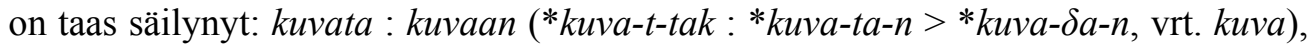
lainata (vrt. laina), tervata (vrt. terva). Supistumaverbityyppi on nykyään erittäin produktiivinen ja siihen on liittynyt paljon myös lainoja, joiden vieras originaali on verbi: vrt. kelvata : kelpaan (vrt. germ. * $\chi$ elpa-), maalata : maalaan (vrt. muinaisruotsin māla), pestata : pestaan (muinais- ja nykyruotsin fästa).

Toinen tyyppi on sellainen, että johdin liittyy konsonanttiseen tai yksitavuiseen vokaaliseen kantavartaloon. Kiistattomia vanhoja verbikantaisiajohdoksia ovat nostaa, vartalo nos-ta- (verbivartalosta nouse-); pistää, vartalo *pis-tä- (verbivartalosta *pise$>$ pysy-); päästää, vartalo pääs-tä- (verbivartalosta pääse-). Nominikantaisia taas ovat jäätää, vartalo jää-tä- (kantavartalo nomini jää); kaartaa (vrt. kaari), kannustaa (vrt. kannus). Tähän tyyppiin on mukautunut myös joukko vanhimpia verbilainoja, kuten niittää (niit-tä-, vrt. germ. *snīp-ela- 'leikata'), sietää (vrt. germ. *stē- > muinaisruotsin stā 'seisoa', myös 'sietää'; vrt. engl. stand kielteisenä myös 'sietää' jne.).

Tällaisten johdosten joukossa on jo useita, joiden hahmottaminen johdokseksi ei enää ole aivan selvää. Sellaisiksi voi kai lukea vaikkapa verbit kastaa (johdos substantiivista kasi 'kaste, kosteus'), säätää (? johdos substantiivista sää 'säie', ks. SSA III 246) tai vuotaa (johdos substantiivista vuo 'virran uoma; virta'). Nykykielessä täysin perusvartalon veroisia ovat sellaiset vanhat johdokset, joiden kantasana on kielestä hävinnyt tai muuttunut tunnistamattomaksi: ostaa (*wos-ta-), kantasana on ollut substantiivi *wosa 'kauppatavara', vanha indoeurooppalais-esigermaaninen laina, jonka originaalia edustaa nykysaksan Ware '(kauppa)tavara'; pistää (vrt. yllä). Tässä artikkelissa tarkastelen joitakin hämärtyneitä -ta-/-tä-johdoksia, etenkin vanhoja lainaverbejä, joissa tämä johdin esiintyy.

Lainaverbejä on muodostettu useilla muillakin suffikseilla. Otan tässä lisäksi esiin vain joitakin sellaisia verbejä, joissa on -(i)sta-/-(i)stä-suffiksi. Mukana on myös yksi omakantainen verbi. Suffiksia voi pitää yhdysperäisenä suffiksina perussuffiksista -ta-/-tä- (ks. Hakulinen 2000: 297).

Käsittelen seuraavien verbien etymologioita: 1. hoitaa (hoiva), 2. hyötää, 3. höystää, höistää, 5. kaataa, 6. kostaa, 7. kuristaa, 8. ottaa, 9. pettää, 10. *taistaa, taisto, taistella. Lisäksi käsittelen verbien hyötää ja höystää kantasanaksi katsomani adjektiivin 4. hyvä etymologiaa. Alaviitteissä koskettelen lyhyesti vielä etymologian kannalta verbejä syöksyä/syöstä ja tunkea (alaviite 7, alaviite 13) ja nominia maa (alaviite 10). 


\section{I. hoitaa, hoiva}

Verbin yleinen merkitys on suomessa 'hoivata, pitää huolta; ohjata' (SSA I 169). Sen levikki on yleisitämerensuomalainen (vain lyydistä ja vepsästä ei ole kirjattu esiintymiä) ja merkitys on kaikkialla lähes sama. Rinnakkainen substantiivi hoiva osoittaa, että etymologian kannalta huomionarvoinen ja vanhin merkityssävy on ollut 'hoivata, suojata, suojella'. Tämä sävy tulee hyvin esiin myös viron vastaavan verbin hoida : hoidma merkityksen määrittelyssä, jonka Wiedemann antaa suuressa viron kielen sanakirjassaan (p. 704): hoidma "behüten ['suojella'], bewahren, schützen ['suojata, suojella'], hüten ['hoivata'], schonen, sparen, aufbewahren"; vrt. myös katus hoiab vihma "das Dach ist regenfest", siis 'katto suojaa sateelta, on sateenkestävä'. Sama sävy näkyy erityisesti myös suomen geminaatallisessa murrevariantissa hoittaa 'suojata tuulelta' ("skydda [för vinden), gifva skydd 1. lä") ja sen johdoksessa hoitto 'tuulensuoja' (luodon varjossa on hoitompi "har man bättre skydd (för vinden)", Lönnrot, lisävihko 28; SSA I 169).

Substantiivilla hoiva 'huolenpito, hoito; suoja (esim. myrskyltä); lievennys, lepo, virkistys, apu' on vastine vain karjalassa, samassa merkityksessä (SSA I 169). Verbi ja substantiivi eivät ole johtosuhteessa keskenään, kumpaakaan ei voi johtaa toisesta. Siksi on oletettu ja oletettava lyhyempää vartaloa *hoi-. Siitä on toisaalta johdettu -ta-suffiksilla verbi hoitaa (= johdettu vartalo hoi-ta-), toisaalta substantiivi hoiva (=hoi-va). Vanhoissa sanakirjoissa (Ganander I 175; Renvall I 81; Eurén 63; Lönnrot I 182) mainitaan tosin myös asu hoipa, mutta se voi olla teorioitu muoto, koska nykymurteissa sellaista ei lainkaan esiinny. Jos se todella olisi hämärtynyt partisiippi, odottaisi toki nimenomaan asun *hoipa säilyneen substantiivina, varsinkin kun vartalo *hoi- on jo hävinnyt kielestä. Onhan - $p$ - säilynyt myös substantiivissa syöpä 'cancer', partisiippi verbivartalosta syö- (infinitiivi syödä), joka sentään on normaali verbi kielessä; vrt. edelleen esim. hyvin-voipa, verbivartalosta voi- (inf. voida), hyvän-suopa verbistä suo-, suoda. Partisiipiksi tulkitsemista vastustaa jossain määrin myös semantiikka. Jos *hoi- olisi vanha verbivartalo, miksi sitä vastaava substantiivi olisi kehittynyt sen preesensin partisiipista? Ei myöskään partisiippi voi-pa merkitse voimaa, eikä partisiippi syö-pä syömistä, muista puhumattakaan. Pikemminkin hoiva on vanha -va/-vä-johdos, jollaisia on johdettu nominivartaloista: vrt. ora-va, ota-va, pella-va, juure-va. Tämän johtimen vanhin asu on ollut ainakin osittain $-k a /-k a ̈$, mutta $-v a$ on silti alkuperäinen useissa sanoissa: vrt. saamen oar'ri 'orava' ja boar'ri 'pieni lautta', jotka on palautettava asuihin *orava ja *porava (jälkimmäisestä itämerensuomessa sisäheiton kautta *porva > suomen parvi). Jos siis *hoi- on substantiivivartalo, sen alkuperäinen varhaiskantasuomalainen vokaalivartalo on ollut joko *šoji tai *čoji tai yhtä hyvin pitkävokaalinen *šōji tai *čóji. Pitkävokaalisesta asustakin tulisi nimittäin myöhemmin tässä johdoksessa vaadittava (ainakin myöhempi) konsonanttivartalo *hoj- > *hoi-; vrt. myös perusvartalo voi 'butter', josta johdos voitaa 'voidella' (kaikkialla itämerensuomessa), johon tunnetusti on rekonstruoitu pitkä vokaali, varhaiskantasuomen *vōji. Johdoksissa hoitaa ja voitaa on siis sama johtosuhdekaava. 
Mutta mistä tällainen nomini on tullut kieleen? Mikään "deskriptiivinen" vartalohan se ei voi olla. Kun sen merkitys osoittautui olleen lähinnä 'suoja', se selittyy iranilaiseksi lainaksi samasta iranilaisesta sanasta, josta myöhemmin on lainautunut juuri suoja (ks. Koivulehto 2001b: 363-364). Iranilaisessa sanassa on sananalkuisena konsonanttielementtinä ollut ieur. *sk'-, josta myöhemmin on kehittynyt äännelaillisesti *sć-, joka taas jo hyvin varhaisessa iranilaisessa vaiheessa on depalataalistunut asuun *sts-; arjalaisen kieliryhmän iranilaisessa haarassa tämä depalataalistuminen tapahtui äännelaillisesti. Myöhemmissä vaiheissa tästä kehittyi pelkkä $*_{s-.}{ }^{1}$

Ensi tavun vokaalina on ollut pitkä $* \bar{a}$, joka on ilmeisesti ääntynyt hieman labiaalisesti, koska sen vastineena on suomalais-ugrilaisella taholla usein $* \bar{o}$, joka on fonotaktisista syistä voinut toteutua myös lyhyenä *o:na. Tällaisia lainoja ovat esim. juoni, ora ja suoja). Kantairanissa vastaava muoto on ollut äännelaillisesti *sāya $-=$ nykypersian sāya, joka merkitsee 'varjo; suoja, apu, puolustus', "Schatten; Schutz, Beistand, Verteidigung", "shadow; protection"; nuoremmassa avestassa on todettu asu a-saiia "der keinen Schatten wirft" (PDW 400; PED 645; EWAia I 559; persiassakin yhtymässä ieur. ${ }^{*} s k^{\prime}>*_{s}$, vaikka muuten ieur. $* k^{\prime}>* t s>$ avestan $s$ / muinaispersian $\theta$ ). Muinaisintiassa vastineena on chāyá 'varjo; suoja', "shadow; shelter, protection" $\left(\mathrm{M}-\mathrm{W}\right.$ 406). ${ }^{2}$

Itämerensuomen suoja-sanan suhteellisen myöhäinen lainautumisaika näkyy siinä, että sen sananalkuinen $s$ - selittyy parhaiten myöhemmän kantairanin sibilantista $*_{s-}$. Äänteellinen paralleeli on sm. vasa = saaI vyesi 'vasa, poron vasikka' = mordvan vaz 'vasikka' $\leftarrow$ myöhäiskantairanin *vasa 'vasikka' (<*vatsa). Samaa myöhäisehköä lainautumisaikaa edellyttää sekin, että siinä on jo pitkä vokaali $* \bar{o}>u o$, vaikka sana on $a$-vartaloinen. Aikaisemmin pitkä vokaali saattoi esiintyä perusvartaloissa vain alkuperäisen $*_{i}$ :n (eli $\left.* e: n\right)^{3}$ edellä. Siksi on todennäköistä, että rekonstruoimassani itämerensuomen $i$-vartaloisessa substantiivissa on originaalin mukaan ollut pitkä vokaali: *šoji tai *čóji. Muutenkin vanhoissa lainoissa on usein $i$-vartalo, huolimatta originaalin vartalotavun vokaalista, etenkin silloin, kun ensi tavu on raskas. Pitkä vokaali ei kuitenkaan voinut fonotaktisista syistä myöhemmin säilyä pitkänä, vaan lyheni: vrt. voi 'butter'<*vōji; vrt. verbi voitaa.

Tarkka äänteellinen paralleeli tälle etymologialle, eli siirtyminen $i$-vartaloisuuteen ja pitkä $* \bar{o}$ vastaamassa arjan pitkää $* \bar{a}$ :ta näkyy arjalaisessa, todennäköisesti iranilaisessa lainassa juoni 'jono, rivi; matka, reitti; ura; salahanke' = saaE juone 'tie' = md.jan 'polku' (SSA I 250) <*jōni Ł arjan *yāna- 'polku, suunta, matka' (M-W 849);

\footnotetext{
1 Indoeuropeisti Alexander Lubotsky on esittänyt, että ieur. * $s k$ ja * $s k$ ovat langenneet iranissa yhteen ja että ei ole syytä rekonstruoida erikseen kahta eri yhtymää: kaikki voidaan selittää lähtien ieur. ${ }^{*} s k$ :sta (Lubotsky 2001; ks. erit. 34-35, 53-54). Joka tapauksessa hänenkin mukaansa on tässä sanassa rekonstruoitava varhainen indoiranin $* s c ́$, josta siis varhain on depalatalisoitunut varhaiskantairanin affrikaatta, myöhempi iranin *s-.

2 Kantaindoeuroopan asu on (traditionaalisesti) *sk'a ây - eikä suinkaan *skiyā, kuten Joki (1973: 330) ja Rédei (1986: 58) virheellisesti esittävät.

3 Alkuperäinen * $i$ tarkoittaa tässä vanhaa kantavartalon toisen tavun * $i$ :tä, joka aikaisemmin ja vieläkin osittain rekonstruoidaan *e:ksi kuten *käti = aik. *käte 'käsi'.
} 
johdos verbistä 'mennä, kulkea', mint. yā- 'mennä, kulkea' (< ieur. *yah $h_{2^{-}}<*^{*} y h_{2^{-}}$ (EWAia II 407).

Varhaiskantasuomen $* \check{s}$ tai $*_{c}$ vastaamassa kantairanin sibilanttia $*_{s}\left(\right.$ tai $\left.*_{z}\right)$ eli aikaisempaa varhaiskantairanilaista ei-palataalista affrikaattaa $* t s($ tai $* d z$ ) (Mayrhofer 1989: 4) tunnetaan useissa muissakin tapauksissa. Iranilaiset lainat voi tunnistaa juuri tästä originaalien palataalisuuden kadosta (mikäli niissä on tuo affrikaatta ollut). Olen käsitellyt kyseisiä äännesubstituutioita perusteellisesti useita kertoja aikaisemmin (Koivulehto 1999: 219-220; 2000: 34-38; 2001a: 252-257; 2001b ja vielä 2007), joten viittaan tässä vain kyseisiin artikkeleihin. Myös kaksinkertaiselle lainautumiselle - eli nuoremmassa lainassa $s \sim$ vanhemmassa lainassa $h$ - löytyy paralleeli, nimittäin ink. iso 'halu, himo', vi. isu 'halu, himo, ruokahalu' (suomessa vain verbijohdos isota 'olla nälissään') vi. iha 'halu, mieliteko, (into)himo' (Koivulehto 2001b: 359-371). Lopuksi esitän vielä edellä käsittelemäni etymologiat tiivistelmänä:

Verbi hoitaa (hoi-ta-) 'hoivata, pitää huolta; ohjata' (johdos hoito), murt. myös hoittaa (hoi-tta-) 'suojata tuulelta' (hoitto 'tuulensuoja') ja substantiivi hoiva (hoi-va) 'huolenpito, hoito; suoja (esim. myrskyltä); lievennys, lepo, virkistys, apu' ovat kumpikin itsenäisiä johdoksia perusvartalosta, substantiivista *hoi-/*hōji- < vksm. *šōji tai *čojji *'suoja'. Varhaiskantasuomen substantiivi taas on lainaa varhaisiranilaiselta taholta: $\leftarrow$ varhaiskantairanin *(s)ts $\bar{a} y \bar{a}{ }^{*}$ 'suoja, varjo' > kantairanin *s $\bar{a} y \bar{a}-=$ avestan *s $\bar{a} y \bar{a}=$ nykypersian $s \bar{a} y a>$ ' 'varjo, suoja; puolustus' = muinaisintian $\operatorname{ch} \bar{a} y \bar{a}$ 'varjo; suoja'. ${ }^{4}$

\section{2. hyötää}

Lönnrotin sanakirjassa yhdistetään verbit hyötää ja hyöstyä (sic!) adjektiiviin hyvä, tosin tavalla, jota nykyään ei voi pitää täysin oikeana (I 263 s.v. hyö: hyö olisi kirjoittajan mukaan supistuma asusta hyä, joka taas olisi $=$ hyvä). Tätä ajatusta en ole huomannut myöhemmin hyödynnettävän, ainakaan SSA ei siitä mainitse mitään kirjallisuusosassaankaan. Kuitenkin yhdistelmä on nimenomaan semanttisesti mutta nähdäkseni myös äänteellisesti moitteeton, kunhan katsotaan etymologiaa vähän toiselta kannalta.

Tarkastelen aluksi hyötää-sanueen sisäistä rakennetta, mistä samalla käy ilmi sen semanttinen liittyminen adjektiiviin hyvä. Tämän sanapesyeen muodollisena kantana on lyhin perusvartalo *hyö-. Perusverbinä voidaan pitää -tä-suffiksilla johdettua verbiä hyötää (= vartalo hÿ̈-tä-), joka nykykirjakielessä merkitsee transitiivisesti 'kasvattaa kasveja [normaalia nopeammin] kasvihuoneessa tai hyötölavassa'. Murteissa

4 Tunnetusti sm.-ugr. kakuminaalisen affrikaatan ja suhusibilantin eroa ei puutteellisen evidenssin takia voi aina pitää varmana, joten lainoissa on voinut olla myös vain *š: huhta 'kaski' (mordvan mukaan näyttäisi kyseessä kyllä olevan affrikaatta), juuri käsitelty vartalo *hoi-, samoin äsken mainittu viron iha 'halu, mieliteko, (into)himo', edelleen komin $u \check{z}=$ marin ožo 'orihevonen'. Vihdoin on iho (levikki: itämerensuomi, saame, mordva, mari, komi) jonka saamen vastine assi 'kesi' nimenomaan edellyttää pelkkää suhusibilanttia *šs (Koivulehto 2001b: 369-371). On kuitenkin huomattava, että iho-sanan iranilaisessa originaalissa oli siis myöhemmin soinnillinen sibilantti $*_{z}$, ja soinnillisen $*_{z}$ :n vastineena on vanhoissa germaanisissakin lainoissa nykyään $h$. 
tarkalleen tämä verbiasu esiintyy vain sporadisesti, sekä transitiivinen että intransitiivinen käyttö on todettu: Se hyätee (= hoitaa hyvin) omaa lehemäänsä (Ikaalinen); pehe (= pensas) kasvooh hyötää (Rantasalmi) (SMS IV 354). Lönnrotin sanakirja tuntee verbin intransitiivisena: hyötää : hyödän "skjuta fram, drifva upp" (siis 'versoa, kasvattaa versoja, vesoja'), hyötö : hyödön "framskjutning; rotskott, telning", 'versominen; [juuri]vesa' (I 263). Kirjakielen transitiivinen käyttö voisi olla tietoinen uudennos, mutta sporadinen murremuoto on varmaankin jo vanha, vaikka jo häviämässä ollut. ${ }^{5}$ Verbin aktiiviseksi partisiipiksi selittyy adjektiivi hyötävä 'hyväkasvuinen, hyötyisä' (SMS IV 353).

hyötää-verbin passiivis-refleksiiviseltä johdokselta näyttää verbi hyötyä : hyödyn 'saada etua, voittoa, vaurastua', jonka senkin merkitys on alkujaan liittynyt 'hyvin, rehevästi kasvamiseen'. Murresanakirja (SMS IV 352) mainitsee yleisen merkityksen rinnalla 'kasvaa hyvin, rehottaa; lihoa, vahvistua, voimistua, menestyä': havupuut tiel oikei hyötyy kun tie on kankasmaata (Hollola). Samavartaloinen substantiivi hyöty 'etu' jne. on niin ikään murteissa myös '(lehti)puun kannosta t. jnk muun puuvartisen kasvin juuresta versova taimi, vesa; vuosikasvain' (SMS IV 350). Suhteella hyötyä : hyöty on paralleeli tapauksessa syntyä : synty 'alkuperä' välillä (tästä verbistä, jonka -ty-aineksen olen tulkinnut johdinperäiseksi [ $\longleftarrow{ }^{*}-t \ddot{a}$-: *sün-tä-], ks. tarkemmin Koivulehto 1999: 222-223). Huomattakoon lisäksi verbi suoda : suon, jonka olen selittänyt asusta *suva-, joka puolestaan on selitykseni mukaan arjalainen laina (vrt. mint. suváti 'suo' [yks. 3. p.], ks. Koivulehto 1999: 230). Samaa lainakantaa on varmaan suvaita: suvaitsen.

Semantiikan kannalta viitattakoon vielä adjektiivin hyvä johdokseen hyvyys, jonka vastine karjalassa ja lyydissä, hyvys, hüvüz, merkitsee myös 'hyötyä' (SSA I 201).

Entä miten verbi hyötää on äänteellisesti johdettavissa adjektiivista hyvä =

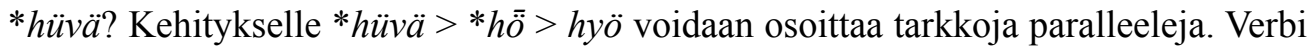
vuotaa on johdos substantiivista vuo 'virran uoma, virta' (SSA III 476; 472), joka taas on kehittynyt asusta $* u v a(>* \bar{o}>* v \bar{o})$, jota vastaa eteläsaamen $u w e, u v v e$ 'virta, virtaus' ( $v: n$ edellä $u$ on jäänyt kehittymättä $* o: k s i)$. Toinen vartalovariantti on verbissä pohjoissaamen avvit 'vuotaa (veneestä)' (Sammallahti 1988: 542; SSS 9). ${ }^{6}$ Vanhempi kaksitavuinen äänneasu näkyy vielä johdoksessa uve, joka esiintyy yhdyssanassa uveavanto 'itsestään syntynyt avanto, virtaaman aiheuttama aukko jäässä' (SSA III 381). Suomen vyö on kehittynyt vanhemmasta asusta * üvä ( $>$ saamen avvi 'vyö', Sammallahti 1988: 536; SSA III 477). Näin siis (*šüvä >) *hüvä >*hö > *hyö $\rightarrow$ hyötää kuten $* u v a>{ }^{*} v \bar{o}>v u o \rightarrow v u o t a a$. Sananalkuinen $v$ - on kehittynyt äännelaillisesti pitkän $* \bar{o}: n$ eteen, kuten esimerkiksi tapauksessa vuota (balttilainen laina,

5 Sitä pitempi asu murteissa on hyövätä 'kasvaa hyvin, menestyä, onnistua' (HämeK, Kym, KesE); muita tähän liittyviä merkityksiä ovat 'onnistaa, luonnistaa' ja 'hyödyttää, kannattaa, maksaa vaiva'. Tämä verbi tuskin edustaa supistumaverbiä *hyödätä : hyötään, koska astevaihtelua ei esiinny. Sen sijaan sen rakenne rinnastuu verbiin muovata muoto (vrt. SSA II 179) eli siis hyövätä hyötö. Kaisa Häkkisen mukaan muovata voisi kuulua venäläisen lainasanaan muota 'muoto' (NES 738).

6 Ante Aikio (henkilökohtaisesti 8.7.2008) lisäsi tähän vielä johdosverbin pohjoissaamen avvidit 'vuotaa'< kantasaamen *eve-têe-. Epä-äännelaillinen *e on hänen mukaansa luultavasti seurausta "labiaalidissimilaatiosta" $* o>>$ e labiaalikonsonantin vieressä. 
vrt. liettuan óda 'nahka, vuota'). Vrt. edelleen *müyä- > myö-, josta mm. partitiivi myötä 'mukana' (SSA 190; Sammallahti 1988: 546) = saaP mayyẹ- 'jälki-, perä-, taka-' (SSS 279).

Miksi sitten *hyö ei esiinny - tai on kadonnut - itsenäisenä adjektiivina? Varmaan siksi, että kielessä ei ole muitakaan yksitavuisia adjektiiveja. On myös vain syvä eikä *syö; vrt. kuitenkin syö-kse- : syö-ksy-. ${ }^{7}$ Kielessä oli varmaan horjuvuutta (vrt. vuo $u v e$ !), joten kaksitavuisuus voitti adjektiivissa, siitä varhain johdetussa verbissä taas yksitavuisuus.

Maininnan ansaitsee vielä ilmaisu hyötähyviään 'aiheettomasti, syyttä', rinnalla hyötähyvyyttään yms. (SMS IV 353, 313), jolla on vastine vepsässäkin: hödhüvid (SSA I 203); vrt. niine hyvineen 'tyhjin toimin' (SMS IV 313). Tuskin hyötä- tässä liittyy suoraan hyöty-sanueeseen, pikemminkin se on partitiivi asusta *hyö 'hyvä', kuten myötä on partitiivi asusta *myö-: vrt. toisaalta hyvä(ä)hyvyyttään.

\section{3. höystää, höistää}

Lönnrotin sanakirjassa esiintyy myös verbi hyöstyä "hastigt tillväxa, förkofras", 'kasvaa nopeasti, kehittyä, edistyä'. Muoto tavataan harvinaisena myös murteista: hyöstyä 'menestyä, kasvaa hyvin, voimistua' (SMS IV 349). On myös kirjattu sanat hyöste 'täyte', hyöstykasvuinen 'hyvin kasvanut, hyötykasvuinen'. Vanhasta kirjasuomesta on tavoitettu yksi esiintymä adjektiivista hyöstäväinen 'lannoittava' (VKS I 763). Näiden asujen täytyy kuulua yhteen tavallisemman -öy-tyypin, verbin höystää 'lannoittaa, väkevöittää, voimistaa', myös 'panna höysteeksi, suurustaa, maustaa' ja sen pesyeen kanssa; vrt. myös höystö 'peltoon pantava lanta' jne., samaa merkitsevä höyste jne. (SMS IV 686, 688). Vanhassa kirjasuomessakin oli myös höystää 'lannoittaa' ja höystö, höyste 'lanta' (VKS I 807). Diftongin - öy- rinnalla tavataan -öi-muotoa (jo Agricolalla) ja se esiintyy etenkin itämurteissa (SSA I 219). Samoin karjalan kielessä: höisteä 'höystää; lannoittaa; ulostaa', höistyä 'höystyä; kehittyä, vaurastua, tuuheta', höiste, höistö 'höyste; lanta'; lyydistä on kirjattu höšte, höštö 'lanta'.

Diftongieroa hyöstää höystää voisi kai selittää sillä, että vanhempi -yö- on muuntunut jossain vaiheessa - öy-:ksi; tällaista muuntumistahan muutoinkin sporadisesti esiintyy; esimerkiksi käy adjektiivi juohe(v) $a \sim$ jouhe(v)a 'tasainen' yms. (SMS V 254, 348). Asu hyöstää olisi tämän mukaan siis alkuperäinen, höystää olisi siitä muuntunut muoto.

\footnotetext{
7 *sō- näyttää siis kuitenkin sekin esiintyvän, nimittäin translatiivisessa verbiparissa *sō-kse-/*sō-ksü> syöstä : syöksen, syöksyä : syöksyn (-ks- lienee peräisin translatiivista, ks. Hakulinen 2000: 298). Näin saamme johdokselle luontevan semanttisen motivaation: syökseminen/syöksyminen on alun perin alaspäin, syvään, syvyyteen syöksemistä/syöksymistä. Tälle merkityssuhteelle löytyy paralleeleja: vrt. germ. *daupja- 'painaa upoksiin' (> misl. deypa id., saksan taufen 'kastaa'), joka on samaa kantaa kuin englannin deep, saksan tief 'syvä'; latinan praeceps 'äkkijyrkkä, jyrkästi laskeutuva', (subst.) 'jyrkänne, syvyys', tästä verbijohdos praecipitare (trans.) 'äkkiä, suinpäin sysätä, syöstä alas; syöstä häviöön, onnettomuuteen', (intrans.) 'syöksyä alas; sortua'. SSA:n mukaan verbi olisi refleksiivinen johdos syödäverbistä ('syödä itsensä läpi'), mikä semanttisesti on tietenkin kovin väkinäistä. juo-kse- ei ole paralleeli, koska 'juokseminen' on alun alkaen 'veden virtaamista', juokseva vesi 'fließendes Wasser' (ks. Koivulehto 1999: 18, alav. 7).
} 
Parempi selitys on mielestäni kuitenkin se, että alkuperäinen asu on höistää ynnä johdokset höiste/höistö ja höystää siitä labiaalistunut länsisuomalainen asu (Juslenius 1745: 110). Vanhin kirjattu asuhan onkin höistää (Agricola), joka esiintyy, kuten juuri mainittiin, itämurteissa, karjalan kielessä ja lyydissä. höistää on siis alun perin morfemaattisesti *hö-istä-; kuten esim. soistaa (soistua) on *sō-ista- (*sō-istu-) kannasta ${ }^{*} s \bar{o}->$ suo. Pitkä vokaali on tietenkin lyhentynyt -ista-johtimen edellä. Suffiksistahan täytyy tässä selityksessä olla kyse, koska kolmen konsonantin **-jst-yhtymää sanan sisällä ei ole voinut olla olemassa (ks. myös Koivulehto 1981: 348-360: paistaa, loistaa jne.). Harvinainen hyöstää olisi tässä tapauksessa saanut diftonginsa tarttumana jo edellä käsitellystä verbistä hyötää.

Semanttisesti verbin höistää/höystää johtaminen adjektiivista hyvä on ongelmatonta. Verbihän merkitsee juuri hyväksi tekemistä, maan parantamista, erityisesti lannoittamista sekä ruoan ravintoarvon ja maittavuuden parantamista. Tarkka semanttismorfologinen paralleeli on ruotsin verbi göda 'lihottaa, syöttää, ruokkia; lannoittaa' (johdos gödsel 'lanta'), joka on johdos adjektiivista god 'hyvä'.

\section{Ekskurssi: hyvä}

Entä voisiko kantasanan hyvä alkuperää etsiä lainaoriginaalista? Sen levikki kattaa koko itämerensuomen. Lisäksi tämän adjektiivin on katsottu esiintyvän mordvassa: mdE tšiv 'hyvä, kelvollinen', mdM tšiva 'vieraanvarainen' (MoW I 272; SSA I 201). Saamesta on tähän liitetty kysymysmerkillisenä perusvartaloinen verbi savvit 'parantaa; parantua, arpeutua' (SSA ibidem; vrt. SSS 383; ILW III 85). SSA luettelee koko joukon lisää kysymysmerkillisiä vastineita etäsukukukielistä. Niiden vokaalit eivät kuitenkaan sovi yhteen itämerensuomalais-saamelaisen vokaalin kanssa, ja sanansisäisen *-v-:n asemesta niissä näyttää olevan gutturaalinasaali *- $\eta-$. UEW (I 499) lähteekin asusta *̌̌ enä, joka kyllä sopisi itämerensuomeen mutta tuskin enää mordvaan (mordvassa odottaisi siinä tapauksessa kehitystä $*_{\eta}>*_{j}$; vrt. Bartens 1999: 49), eikä ainakaan saameen.

Saamen verbin vokaali vastaa etymologisesti itämerensuomen *i:tä tai * $\ddot{u}$ :ta. Mutta mordvan *i olisi tällöin poikkeuksellinen, mordvassa odottaisi *e:tä. ${ }^{8}$ Mordvan ja itämerensuomen vokaalien vastaavuuksissa on kuitenkin epäsäännöllisyyksiä, jotka johtuvat lainasuhteista. Sana on lainautunut mordvaan sen verran myöhään, että se ei ole enää osallistunut suppeiden vokaalien avautumiseen. Samanlainen tapaus on esim. sm. huhta 'kaski' mdE tšuvto, mdM šufta 'puu' ( $\longleftarrow$ varhaiskantairanin *tsukta- 'sytytetty, poltettu', osseetissa substantiivina merkityksessä 'palo, palopaikka'; Koivulehto 1999: 225-226); ks. myös ylempänä etymologiaa hoitaa, hoiva.

Tällä kertaa mistään dokumentoidusta iranilaisesta kielestä ei löydy (enää) jälkeä olettamastani lainaoriginaalista, jonka pitäisi olla varhaiskantairanin *tsiva-. Sen sijaan sen läheisessä sukukielessä indoarjassa on tätä adjektiviivia etymologisesti

8 Jos lähtisimme alkuperäisestä * $e$ :stä, mordvan vokaali olisi säännöllinen ja itämerensuomen * $u$ voisi olla labiaalistumisen tulosta: $* e>\ddot{u}$. Saamen verbin olisi kuitenkin siinä tapauksessa oltava laina kantasuomesta, koska sen vokaali ei voi etymologisesti vastata vanhempaa *e:tä. 
vastaava adjektiivi: mint. śivá- 'suopea, hyväntahtoinen, ystävällinen, rakas' ('auspicious, propitious, gracious, favourable, benign, kind, benevolent, friendly, dear", M-W 1074; "günstig, freundlich, hold, lieb, gütig", EWAia II 640). Adjektiivi on tavallinen Rig-Vedasta lähtien. Se esiintyi varsinkin eri jumalten yhteydessä adjektiivina, myös pelottavan Rudra-jumalan eufemistisena epiteettinä ja sittemmin monimuotoisen Śiva-jumalan varsinaisena nimenä (kirjoitetaan nykyään yleensä Šiva). Tämän fallistisen jumaluuden palvonta - vaikka ei nimi - näyttää pohjautuvan jo varhaisen Indus-kulttuurin uskontoon. (Parpola 2005: 70-71, 130-133; EWAia II 640.) Tämän katoasteisen adjektiivin (< ieur. *kiwo-) rinnalla on täysasteinen asu mint. śéva- 'rakas, suopea, läheinen' (EWAia II 654) <*śaiva- < ieur. *kéywo-. Sama täysaste näkyy myös latinan sanansa cīvis (< vanh. ceivis) 'kansalainen' ja muinaisyläsaksan feminiinissä *hī $(w) a$ 'aviovaimo'.

On vaikeata käsittää, että varhaiskantairanissa ei olisi kerran ollut samaa keskeistä erityisesti jumalia kuvaavaa adjektiivia kuin muinaisintiassa. Ovathan kielet aivan lähisukukuisia, samasta kantakielestä polveutuvia arjalaisia eli indoiranilaisia kieliä. Toisaalta indoarjan ja iranin eroaminen on Asko Parpolan mukaan tapahtunut jo n. 1800 eKr., ja kantairania puhuttiin hänen mukaansa Kaakkois-Euroopan hirsihautakulttuurissa ("Timber Grave Culture") jo 1800-1000 eKr. (Parpola 1998: 129-130; Carpelan \& Parpola 2001: 133-134; Parpola 2005: 32). Vanhimmat iranilaiset tekstit ovat myöhemmältä ajalta: avesta (pyhän kirjan Avestan kieli) ajoitetaan n. $800 \mathrm{eKr}$. ja muinaispersian vähäiset piirtokirjoitukset ovat ajalta 521-486 eKr. (Parpola 2005: 29). Iranin kielihaaran uskonnollinen kehitys muotoutui profeetta Zarathuštran vaikutuksesta aivan erilaiseksi kuin kuin indoarjalaisen. Ylijumalaksi kohosi Ahura Mazdā, joka edusti valoa ja hyvää. Näitä voimia vastassa olivat demonit, daêva (Parpola 83), jotka aikaisemmin olivat edustaneet hyviä voimia, kuten näkyy siitäkin, että tästä sanasta on itämerensuomeen lainautunut taivas, varmaankin samalta varhaiselta iranilaiselta taholta kuin tässä perustelemani selityksen mukaan adjektiivi hyvä. Voisi ajatella, että tuota indoarjan adjektiivia *śivá- vastaava varhaiskantairanin *tsiva- (olisi myöhemmin *siva-) katosi kielestä uusien uskonnollisten virtausten mukana. Vaikka se alun alkaen olikin adjektiivi, joka ei välttämättä ollut vanhojen jumalien epiteetti, on se silti voinut kielitajussa liittyä siksi paljon näihin, että sen käyttö ei muissakaan yhteyksissä ollut enää sopivaa. Tässä olisi yksi selitys adjektiivin katoon iranista.

Itämerensuomen labiaalivokaali $* \ddot{u}$ selittyy labiaalisoitumisesta $* i>* \ddot{u}$ labiaalikonsonantti *v:n edellä. Paralleeliesimerkkinä on tunnettu kehitys sm. syvä $<*$ sivä (< vksm.*tivä > saa. davvi 'pohjoinen').

Saamen verbi savvit 'parantua; parantaa' (SSA I 201; SSS 383) kuulunee tähän (siitä johdos sav'vot 'umpeutua [haava, tie], arpeutua, parantua'). Onhan ainakin itämerensuomesta tiedossa esimerkkejä, joissa adjektiivivartalo yksinään muodostaa myös vastaavan verbin: sm. kuiva- (inf. kuivaa) adj. kuiva, sm. sula- (inf. sulaa) adj. sula. Silti tuntuu vähän oudolta, että saamessa olisi olemassa vain tällainen perusvartaloinen verbaalistunut adjektiivi. Saamen spesialistit voisivat ottaa tähän kantaa.

Sananalkuiseen kakuminaaliaffrikaattaan $* \check{c}$ - viittaa selvästi ainoastaan mordvan asu, koska itämerensuomen suhusibilantti voisi olla alkuperäinenkin. Saamen verbi - jos se kuuluu tähän - taas vaatii nimenomaan suhusibilanttia. Voisi kyllä ajatella 
sitäkin, että saamen sana olisi vanha laina varhaiskantasuomesta, saatu sen jälkeen, kun affrikaatassa oli tapahtunut varhainen deokkluusio, kuten Petri Kallio (2007: 231) on hiljattain esittänyt. Myöhemmin saamessa olisi sitten tapahtunut säännöllinen kehitys $* \check{s}>s$. Joka tapauksessa konsonanttisuhde itämerensuomen ja varhaiskantairanin välillä on sama kuin tapauksessa sm. huhta ja edellä mainittu hoitaa.

\section{5. kaataa}

Suomen verbi kaataa 'to fell, to hew' ('kaataa heinää, metsää'); 'to pour' ('kaataa nestettä'), refleksiivisenä kaatua 'to fall', rajoittuu levikiltään vain itämerensuomeen, eikä se silläkään alueella esiinny (ainakaan nykyään) kaikkialla. Paitsi suomesta se on kirjattu ainoastaan inkeroisesta, karjalasta, lyydistä ja lisäksi viron koillismurteesta, missä se on varmaankin lainaa suomesta (SSA I 267). Minkäänlaista etymologiaa tälle verbille ei näy esitetyn (ks. kuitenkin nyttemmin Janhunen 2007: 219, 221-222 ja tämän artikkelin alaviite 12).

Vanhassa verbissä vartalo kaata- ei voi olla alkuperäinen perusvartalo, koska kaksitavuisessa $a$-vartalossa ei ole voinut vanhoissa perusvartaloissa olla pitkiä avoimia vokaaleja (Sammallahti 1988: 486-490). Verbissä raataa tämä rakenne kyllä jo esiintyy, mutta sehän onkin myöhäinen laina venäjästä ja -ta-aines kuuluu etymologisesti vartaloon: vrt. ven. stradát' 'kärsiä; tehdä ankarasti työtä' (SSA III 35). Näin ollen kaataa-verbissä täytyy olla suffiksi -ta-. Etymologinen rakenneanalyysi on siis kaksimorfeeminen *kaa-ta-. Samaa rakennetyyppiä ovat verbit hyytää/hyytyä,jäätää/ jäätyä, maatua, päätyä, sä̈̈tää. Verbin suhteelliseen vanhuuteen viittaa sekin, että sillä on esiintynyt konsonanttivartaloista taivutusta: infinitiivi kaata, partisiipin perfekti kaannut, kaanneet.

Perusvartaloa $* k a a^{-}=* k \bar{a}$ - ei näytä löytyvän omaperäisestä uralilaisesta tai suomalais-ugrilaisesta kieliaineksesta. Näin päädytään olettamaan sen lainalähtöisyyttä. Tällaisissa yksitavuisissa pitkävokaalisissa vartaloissakaan pitkä vokaali ei ole alkuperäinen, vaan vartalot palautuvat aina alkuperäisiin kaksitavuisiin, joiden konsonantti on varhain kadonnut: maa $<*^{*}$ maxi $\left(<*_{\text {mexi }}<*^{*}\right.$ mixi $)$, saa- 'saada' $<{ }^{*}$ saxi- $\left(<*^{*}\right.$ sexi- $)$, jää $<*$ jäyi (Sammallahti 1988: 546, 553, 543).

Indoeurooppalaisella puolella on tähän originaaliksi sopiva verbijuuri, nimittäin myöhäisieur. $* k a h_{2} w$ - $\left(<* k e h_{2} w\right.$-), jonka merkitykseksi on rekonstruoitu lähinnä *'lyödä, hakata, halkoa' ja jonka levikki kattaa tokaarin, baltoslaavin, germaanin ja latinan (LIV 345-346; perinteisesti *kāu-, $k \bar{u}$-: IEW 535). Germaanissa verbiä edustaa kantagermaaninen "Verschärfung"-verbi * $\chi a w w-e / o-\left(\right.$ siis $\left.<* k a h_{2} w-e / o-\right)$, jossa ${ }^{*}-w w$ - (= kantaskand. ${ }^{*}$-ggw-) on siis ieur. laryngaalisekvenssin myöhempi refleksi. ${ }^{9}$ Germaanisesta verbistä ovat edelleen kehittyneet muinaisenglannin (inf.) hêawan,

9 Indoeuropeisti Peter Schrijver on aikaisemmin (1991: 286) esittänyt, että germaanin verbissä on todennäköisesti ("probably") tapahtunut varhainen laryngaalimetateesi, joten hän lähtee sekundaarisista ablautasuista *kewH-/*kowH-, o-asteesta (siis germaanin *kaww-). Tiedusteltuani häneltä myöhemmin hänen nykyistä kantaansa hän toteaa minulle lähettämässään sähköpostissa (17.7.2003), että hän ei enää pidä tästä ajatuksesta kiinni ja että hänellä ei ole (enää) kantaa germaanisen *-ww-:n synnystä, sekä toteaa, että hän ei (näin ollen) pysty esittämään mitään "zwingendes" etymologiaani vastaan. 
nykyenglannin hew, muinaisyläsaksan houwan, keskiyläsaksan houwen, nykysaksan hauen, muinaisislannin hoggva, ruotsin hugga 'lyödä, hakata'. Mutta nimenomaan germaanissa verbi on vanhastaan ollut käytössä myös merkityksessä 'kaataa', nimittäin 'kaataa metsää, puita, heinää', myös 'kaataa, tappaa eläin'; misl. "om Nedfælden af Træer i Skoven": heggva tré, skóg 'kaataa puita, metsää'; "om Nedmeien af Græs eller Hø": høggva hey 'kaataa (= niittää) heinää'; høggva myös 'lyödä kuoliaaksi, tappaa' (Fritzner II 177); nykyruotsin hugga mm. "med eggverktyg fälla l. avverka 1. avmeja (ngt)", 'kaataa tai niittää teräaseella'; hugga träd, skog 'kaataa puita, metsää'; hugga svedja 'kaataa kaskea', (murt.) 'leikata, niittää (viljaa, rehua tms.)' (SAOB XI H 1324-1325); muinaisenglannin hẽawan "to hew", myös "to few, fell wood" (Bosworth 524; Toller 526), nykyenglannin hew (down) timber, trees 'kaataa metsää, puita' (OED VII 194-195); muinaisyläsaksan houwan 'hakata, lyödä, kaataa', thana-houwan "abschlagen, fällen", 'kaataa puu' (AhdW IV 1304, 1306), nykysaksan hauen mm. 'kaataa puita; kaataa (= niittää) heinää'. Muista indoeurooppalaisista kielistä riittäkööt seuraavat tiedot semantiikasta: tokaari 'lyödä kuoliaaksi, tappaa' (LIV ibid.), liettua káuju : káuti 'lyödä, hakata, tappaa, hävittää' (Fraenkel I 232), muinaiskirkkoslaavi kovq : kovati 'takoa', latina ( $d^{h} e$-preesens) $c \bar{u} d \bar{o}: c \bar{u} d e r e$ 'lyödä, survoa, lyödä rahaa'; tähän lat. caudex = cōdex 'puunrunko, pölkky' (IEW ibid.).

Semanttisesti etymologia on ongelmaton. Merkitys 'tappaa' on tuskin kummallakaan puolella primaari, vaan on ainakin itämerensuomessa kehittynyt luontevasti eläimen, vastustajan maahan kaatamisesta eli 'surmaamisesta'. Samoinhan käytetään ruotsin verbiä fälla 'kaataa': fälla en björn 'kaataa karhu', fälla en fiende 'surmata vihollinen'.

Tarkastelen sitten etymologian äänteellistä puolta. Kantaindoeuroopan verbijuuressa $* k a h_{2} w$ - olevan yhtymän $*-h_{2} w$ - odotettavissa oleva varhaiskantasuomalainen/suomalais-ugrilainen refleksi olisi lähinnä *-x-: *kaxi-. Vokaalien välisenä se on säilynyt varhaiskantasuomeen asti (Kallio 2007: 232; Janhunen 2007: 207), jolloin myöhäiskantasuomeen kehittyy asu $* k \bar{a}-=$ sm. kaa-; vrt. vksm. ${ }^{*}$ maxi $>$ maa. ${ }^{10}$ Voisimme myös teoreettisesti ajatella, että ieur. originaalin puolivokaaliseksi merkitty $*_{\text {-w }}$ - olisi lainansaajataholla tajuttu vokaaliksi ${ }^{*}-u$-. Tässäkin tapauksessa tulokseksi olisi tullut *kaxi-, koska $u$-vartaloita ei vielä tunnettu (vrt. ieur. *med ${ }^{h} u$ - 'hunaja' $\rightarrow$ sm.-ugr. *meti).

Foneettisesti tämä substituutio on luonteva. Indoeurooppalaisen laryngaalin substituutiota foneemilla ural./sm.-ugr./vksm. ${ }^{*}$-x- edellyttävät jo aikaisemmin lainoiksi selittämäni sanat, sellaiset kuin esim. ural. *pexi- 'keittää', ural. *puxi 'puu', ural. *suxi- 'soutaa', sm.-ugr. *toxi- 'tuoda' (ks. lähemmin Koivulehto 1991: 52-67).

\footnotetext{
10 *maxi $<$ *mexi 'maa' on näköjään indoarjalainen laina: vrt. mint. máhi (n.) mahî́ (fem.) 'iso, laaja; maa' (< ieur. *méǵ- $h_{2}$, johdos EWAia II 337-338). Merkitys 'maa' esiintyy feminiinillä myös myöhemmissä indoarjalaisissa kielissä: (yksinomaan) palissa ja prakritissa (Turner 573). Suomalais-ugrilaiseen sanaan on tosin rekonstruoitu $*$, mutta tämä äännesuhde tavataan muuallakin. Rekonstruktion vokaalin on täytynyt olla avoimempi. Toisaalta myös originaalin * $a$ on ilmeisesti foneettisesti ollut lähellä keskivokaalia. Aikaisempi ajatukseni on hylättävä (Koivulehto 1991: 54, alav. 26). Semantiikan suhteen vrt. saa. eana(n) 'maa', johdos vartalosta sm.-ugr. *enä 'iso'.
} 
Myös ural. *näxi- 'nainen' on kehittynyt itämerensuomeen samalla tavalla: väljä pitkä vokaali on säilynyt (Janhunen 1981: 27) myöhemmässä johdoksessa naaras. ${ }^{11}$

Varhaiskantasuomalainen $*_{-} x$ - esiintyy myös toistaiseksi julkaisemattoman etymologian mukaan samassa $*_{\text {soxi- }}>$ mksm. ${ }^{*}$ sō $>$ sm. suo (Kallio \& Koivulehto, tulossa). Esigermaaninen (tai "paleogermaaninen") originaali on selityksemme mukaan ollut *soyg ${ }^{w}-o_{-} / *^{*} s_{s y g}{ }^{w}-i_{-}$, josta varhaisgerm. ${ }^{*}$ saigwa-/*saigwi- > myöhemmin *saiwa-/*saiwi-> goot. saiw-s 'järvi, marskimaa' jne. Varhaiskantasuomessa tuntematon esigerm. sanansisäinen sekvenssi on korvattu foneemilla $*_{-}-x-\left(=*_{-}-\gamma_{-}\right)$; ${ }_{-j} j \gamma(v)-$ ei olisi ollut mahdollinen sekvenssi. Semantiikan suhteen vrt. esim. ruotsin träsk'suo, räme; pieni järvi, lampi' (germaanisesta konsonanttihistoriasta ks. Vennemann 1984: 40-41; Koivulehto \& Vennemann 1996: 172-174).

Milloin $* k a x i->* k \bar{a}$ - -vartaloon on liittynyt johdin -ta-, ei liene tarkkaan ratkaistavissa. Kantauralilainen *kax-ta- ei nykyisen käsityksen mukaan ainakaan sovi, koska konsonanttia edeltävässä asemassa *- $x$ - olisi hävinnyt hyvin varhain ja lisäksi tällaisessa $a$-vartalossa vokaali ei olisi pidentynyt vaan pysynyt lyhyenä $* a$ :na. Tai vaihtoehtoisesti: vokaali olisi säilynyt pitkänä, mutta supistunut pitkäksi $* \bar{o}: \mathrm{ksi}$. Jälkimmäinen vaihtoehto on epätodennäköinen, koska $a$-vartalossa ural. *ńoxma 'jänis' (Janhunen 1981: 242) *o on säilynyt lyhyenä: sm.-perm. johdos *ńoma-la. Sammallahti ei tähän 'jänis'-sanaan rekonstruoikaan *-x-:ää (Sammallahti 1988: 539; ks. toisaalta s. 486). $i$-vartaloissa vokaali kyllä konsonantin edellä piteni, mutta alkuperäinen $* a$ olisi muuttunut pitkäksi $* \bar{o}: k s i-x$-:n kadottua.

Tosiasia on joka tapauksessa, että pitkä $* \bar{a}$ on säilynyt eikä se toisaalta voi olla alkuperäinen, kuten ei myöskään johdoksessa suomen naa-ra(s) vartalosta *nā-. Näin ollen suffiksillinen kaataa-verbi näyttää tulleen kieleen vasta kantauralin aikaa myöhemmin, ehkä vasta keski- tai myöhäiskantasuomeen, kuten varmasti myös naaras tai verbi jä̈̈tää (<*jäyi-), mihin sen suppea levikkikin viittaa. ${ }^{12}$

\footnotetext{
11 Useissa suhteellisen varhaisissa suomessa esiintyvissä indoeur. lainoissa esiintyy laryngaalin vastineena sm.-ugr./vksm. *š. Ne ovat kuitenkin tapauksia, joissa tämän vastineen sijainti osuu konsonantin eteen tai (harvemmin) jälkeen: ehkä, ehtiä, ihminen (vanh. inhiminen), kehdata, pohtaa, puhdas, tahdas, vihdoin (*vihta 'kerta'). Lisäksi on md. ponžavto- 'pohtaa'. Näissä asemissahan olisi vanha *-x- jo kadonnut (tai sitä ei olisi koskaan esiintynytkään), joten tarvittiin uusi substituentti *-š-. Volgalais-permiläisellä taholla on sitten vielä kaksi tapausta, joissa ainakin indoeur. puolella esiintyvät yhtymät $*-w H$ - ja ${ }^{*}-y H-\left({ }^{*} j H-\right)$ : esiarjan *pewHeno- ja *woyHa $\rightarrow$ esipermin ${ }^{*} p e(w)$ šenV ${ }^{*}$ 'jauhoseula' ja $\rightarrow$ md.-mariperm. *wo(j)ša *'haara, oksa'. Ainoa poikkeus näyttää olevan sm.-ugr. *pišä-/*pešä- 'to cook', mutta se ehkä onkin väärä etymologia; tosin se ehkä selittyisi siitä, että oletetun originaalin laryngaalina on ollut palataalinen indoeur. * $h_{l}$. (Kaikesta tästä ks. lähemmin Koivulehto 1991: 72-99.)

12 Juha Janhunen (2007: 219, 221-222) on esittänyt, että "ei olisi mahdotonta", että kantasamojedin *kata- 'tappaa' vastaisi jollakin tavalla itämerensuomen verbiä kaata-, jonka merkitykseksi hän esittää "to kill, to fell, to pour". Merkityksen kuvailu on kuitenkin johdattelua: itämerensuomalaisen verbin ensimmäiseksi, keskeisimmäksi merkitykseksi ei suinkaan voi esittää 'tappaa' vaan nimenomaan 'kaataa', 'to fell'; myös 'to pour' = 'kaataa (nestettä)' (= 'kaataa kannua tms. niin, että siinä oleva neste valuu ulos') juontuu tietenkin tästä. Janhusen mielestä samojedin verbi on kausatiivi verbistä 'kuolla' (kuten varmaan onkin), jota edustaa kantasamojedin kaø- 'kuolla', jossa taas voisi olla primaari juuri * kax-. Miten tästä päästäisiin itämerensuomeen pitkävokaaliseen vartaloon (itämerensuomessa on *koole- 'kuolla') on kuitenkin täysin ad hoc -selitysten varassa, joiden tarkempi selostaminen olisi tässä hankalaa ja tilaa vievää. - Nämä selitykset voi positiivisesti tulkiten ymmärtää yrityksiksi valottaa tähän asti selittämättömän kaataa-verbin alkuperää.
} 


\section{6. kostaa}

Verbi kostaa esiintyy vain itämerensuomessa, eikä tiettävästi sielläkään lyydissä, vepsässä eikä vatjassa: kostaa 'korvata, palkita (pahalla t. hyvällä); kääntää, ohjata, pidättää, palauttaa', ink. (run.) kostā 'palkita', ka. kostoa 'suojata tuulelta', vi. kosta 'kuulua; vastata; kaikua', li. kuost' 'vastata' (SSA I 410). Verbin abstraktisten merkitysten täytyy palautua konkreettiseen merkitykseen 'kääntää (takaisin)'. Näin on selittänyt ainakin jo Lauri Kettunen liivin sanakirjassaan (LiW 174: 'zurückkehren lassen'), ja Lauri Hakulinen (1940: 44) on perustellut tätä laajasti: 'kääntää, palauttaa takaisin'. Suoraan tästä selittyy johdos koste 'koskeen t. jokeen pistäytyvä niemeke, joka kääntää osan vettä viereiseen poukamaan; akanvirta (siis vastavirta, käänteisvirta); tyven, suvanto; linnunansan, -satimen risuista tehty johdeaita 1. vihi (joka siis kääntää, johtaa linnun kulun haluttuun suuntaan, ansaan)'. Hakulinen viittaa vielä Lönnrotin sanakirjan esimerkkeihin: "kosta nuo hevoset, että kääntyisivät toisapäin eivätkä menisi peltoon", "paimen kostaa karjan toiselta laitumen puolelta toiselle", "akkunanpäällinen lauta kostaa päivän sisäänpäin" (SMS VIII 225, 227).

Olen jo aikaisemmin esitelmissäni ja luennoissani (ks. mm. SSA s.v. kostaa) esittänyt verbille esigermaanis-indoeurooppalaisen etymologian: se palautuu äänteellisesti ja semanttisesti moitteettomasti siihen ieur.-esigerm. verbiin, jota edustaa esim. nykysaksan kehren 'kääntää'. Kun en kuitenkaan ole julkaisut etymologiaa painettuna, teen sen nyt. Verbin varhaisemmat attestoidut tytärkieliset asut ovat muinaisyläsaksan kēr(j)an, kēren, muinaissaksin (= muinaisalasaksan) kērian, keskiyläsaksan kēren, myös yleisemmin 'eine Richtung geben' (Lexer I 1552), muinaisfriisin kêra - kaikki merkitsevät 'kehren, wenden, umwenden', siis 'kääntää (takaisin)'; keskiyläsaksan kēren myös yleisemmin 'eine Richtung geben' (Lexer 1552). Verbi on indoeurooppalainen kausatiivi-iteratiivi *goys-éye-, kuten uusi indoeurooppalaisten perusverbien etymologinen sanakirja toteaa (LIV 184), perusverbistä *geys- 'kääntyä' ('sich drehen, sich wenden', LIV mp.). Tästä on äännelaillisesti kehittynyt germ. *kaiz(i)ja-, josta myöhemmin äännelaillisesti *kairija-, josta taas äännelaillisesti äsken esitetyt germaanisten muinaiskielten asut (kehitys $*_{-s-}>$ germ. ${ }_{-}-z$ - johtuu siitä, että verbin kausatiivisuffiksi on ollut alun perin painollinen: *goys-éye-, joten sen edellä oleva sibilantti on soinnillistunut ja muuttunut myöhemmin *-r-:ksi; $r$ :n edellä yläsaksassakin germ. * $a i>\bar{e}$.

Indoeurooppalais-esigermaaninen verbi on lainattu liittämällä siihen -ta-suffiksi, joka itsekin oli myös kausatiivijohdin, kuten originaaliverbinkin suffiksi. Kuten vanhimmissa lainoissa tavallista, suffiksia edeltää konsonanttivartalo. Verbivartaloksi ei kuitenkaan ole tullut **kojsta-, koska kolmen eri konsonantin sekvenssi $*^{*}{ }_{-j}$ jst- oli vielä tuohon varhaiseen aikaan kielenvastainen (vrt. Sammallahti 1988: 480, 482, 492-494). $-j$ - jäi siis pois, ja varhaiskantasuomen verbivartaloksi tuli *kosta- $=$ nykysuomen kosta-. Tällainen puolivokaalin putoaminen näkyy myös esim. myöhäisessä kausatiiviverbissä nostaa (vartalo nosta-), joka on johdettu intransitiivisen perusverbin vartalosta nouse-. 
Sama puolivokaalin putoaminen näkyy vihdoin myös verbissä pohtaa 'puhdistaa viljaa pohtimella' $(<* p o[w] \breve{s}-t a-)$. Indoeurooppalainen originaali on ollut sama verbityyppi kuin kostaa-verbin originaali, nimittäin ieur. -eye- kausatiivi * powH-eye(> germ. *fauja- > mys. fewen, kys. vöuven 'seuloa, puhdistaa viljaa' = mint. paváyati 'puhdistaa'; ks. tarkemmin Koivulehto 1991: 92-93 ja tämän artikkelin alaviite 11).

Suomessa on kyllä myös muodollisesti samannäköisiä diftongillisia verbiasuja, kuten vaikkapa poistaa, toistaa, mutta ne ovat kostaa-verbiä paljon myöhäisempiä johdoksia vartaloista *poi(je)s- ja toise-(toinen). Sellaiset verbit taas, kuten maistaa, paistaa, väistää ovat vanhoja lainoja, joissa alkuperäinen suffiksi on pikemminkin ollut -ista-/-istä-, joten mitään vanhaa *-jst-ainesta ei näissä ole koskaan ollutkaan.

\section{7. $\quad$ kuristaa}

Suomen verbillä kuristaa 'würgen, erdrosseln' on suomen ulkopuolella vastineet inkeroisessa, karjalassa, vatjassa ja virossa: ink. kuristā 'kiristää, hirttää', ka. kuristoa 'kuristaa, kiristää, puristaa', va. kurissā 'kuristaa, hirttää', vi. (murt.) kuristada, kurgistada (myös kurgustada, koristada) 'kuristaa kurkusta, kuristaa kuoliaaksi' (SSA I 448; KKS II 465).

Verbin on ajateltu kuuluvan yhteen verbin kuroa kanssa, joka merkitsee 'ommella huonosti, kursia; vetää tiukalle, kokoon; poimuttaa; kutistua' (SSA ibidem). Tämän verbin semantiikka vie kuitenkin aika lailla toisaalle, kuten näkyy myös johdoksesta kure : kureen 'ryppy' ja saamen vastineesta gorrat 'kuroa, sitoa yhteen' (SSS 190). Kyseessä onkin vain vanha otaksuma. Tällaista verbien johtosuhdetta (ts. -o- : -ista-) ei sitä paitsi suomessa edes tunneta.

Vieraaksi originaaliksi sopii sen sijaan germaaninen verbi, jota muinaisislannissa edustaa kyrkja "erdrosseln", 'kuristaa (kuoliaaksi)' (Vries 341), "gribe en i Struben for at kvæle ham, som om man vil kvæle ham" (Fritzner II 382-383). Nykynorjan murteissa on sama verbi, kyrkja "knipe over strupen, klemme, snøre til" (Torp 357; Aasen 415). Rinnakkaisasuna on muinaisislannissa kvirkja (Fritzner II 376). Tämä verbi on johdos germ. nominista *kwerkō 'kurkku' ja palautuu näin ollen vanhempaan asuun germ. *kwerk(i)ja- (e>i äännelaillisesti toisen tavun $*_{i} / * j$ :n vaikutuksesta). Muinaisislannin kyrkja ja kvirkja ovat sama verbi (Ásgeir 534; Vries 341), vaikka Noreen (1903: 69) esittää ne eri verbeiksi; kyrkja olisi mukautunut ja-verbiksi vanhemmasta asusta *kyrkva.

Germaaninen/varhaisskandinaavinen *kwerk(i)ja- tai myöhempi kantaskand. *kvirkja- lainautui siis itämerensuomeen siten, että germ. *kwe-/*kwi- korvattiin sekvenssillä $* k u$-. $* k v$ - olisi ollut mahdoton, ja germ. $* k w$ - oli itse asiassa alun alkaen labiovelaarinen klusiili, joten klusiilisuuden eli $* k: n$ jääminen pois substituoinnista ei olisi vastannut lainansaajien kuulohavaintoa. Sama labiovelaarin substituutio näkyy esim. kantaindoeurooppalaiseksi lainaksi esittämässäni verbissä * kulki- $\leftarrow * k^{w} e l H-e / o$ $>$ mint. cárati 'kulkee' (Koivulehto 1991: 67-69). Samantapainen substituutio näkyy myös germaanisessa lainassa kuja (merk. myös 'karjatarha') $\leftarrow$ germ. *kwīja $>$ misl. 
kvi 'karjatarha'. Dentaaliklusiilin yhteydessä tavataan sama substituutio: turka-nen 'pahus, peijakas' (lievä kirosana), (vanh. sanak. myös) 'raukka, surkea; ilkiö, noita,

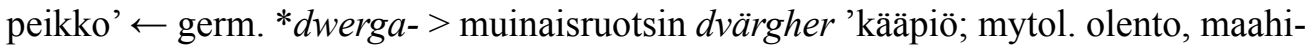
nen' (ks. SSA III 334, siellä kysymysmerkki). ${ }^{13}$

Suomessa on siis lainattaessa sanansisäinen germ. *-k- substituoitu yksinkertaisella *-k-:1la, samoin kuin tapauksessa taistella 'kämpfen' (ks. etymologia nro 10). Näinhän on käynyt vanhimmissa lainoissa. Mutta tätä ei voine yksinään pitää erityisen vanhan lainan merkkinä, koska horjuntaa on olemassa jossain määrin: vrt. esim. länsisuomalainen juko $\sim$ itäsuomalainen jukko $\leftarrow$ germ. *jukan-. Sitä paitsi virossa onkin myös asu kurgistada, joka edellyttäisi vanhaa geminaattaa. Tuskin se on kansanetymologista tartuntaa viron kurk : gen. kurgu 'kurkku' -sanasta - kuten on oletettu - vaan päinvastoin viittaa germaaniseen originaaliin. Muoto kurgustada kylläkin näyttää selvästi tukeutuneen 'kurkku'-substantiiviin.

Itämerensuomen kurkku 'throat' (kaikkialla itämerensuomessa) on varmaankin myös lainattu skandinaavista: $\longleftarrow * k$ werku- 'kurkku'. Periaatteessa se voisi olla hyvin vanha slaavilainen laina $(\leftarrow$ kantaslaavin $* k u r k u>$ muinaiskirkkoslaavin $k r u \breve{k} \breve{u}$ 'kaula', sorbin kyrk 'kaula, kurkku'; muissa slaavilaisissa kielissä yleensä merkitys on 'kaula' ja 'niska'). Olisi kuitenkin aika kumma sattuma, jos verbi kuristaa 'kuristaa kurkusta' $<*$ kuryista- olisi germaaninen, mutta kurkku taas slaavilainen laina.

\footnotetext{
13 Samanlainen substituutio näkyy suomen verbissä tunkea "zwängen, stopfen, (weg)drängen; (ein)dringen" (SSA III 326). Selitän sen originaaliksi germaanisen verbin *pwenga- (> *pwinga- > saksan zwingen, muinaisruotsin pvinga, ruotsin tvinga). Semantiikan kannalta huomattakoon, että SSA:n käännös 'zwängen' on heikkona verbinä samaa pesyettä kuin vanha vahva verbi zwingen ja semanttinen läheisyys näkyy esim. siinä, että sekä zwingen että zwängen voidaan kääntää englanniksi verbillä force. Saamen vastaavassa verbissä coggat on tämän mukaan tapahtunut deskriptiivinen muutos *tu- $>* c u$ (>co-). Samanlainen mutta ilmeisesti myöhempi deskriptiivistyminen näkyy pohjoissaamen sanassa cii$k u$ 'narttu', jota vastaa luulajansaamen dii'ko id. * $t$ - on tässä alkuperäinen; sana juontuu kskand. sanasta

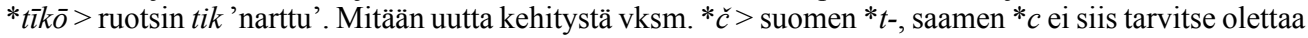
(vrt. Kallio 2007: 231). Toisin Janne Saarikivi (2007: 341-342): hänen selityksessään ei semantiikka kuitenkaan ole kovin vakuuttava; viitataan lähinnä komin adjektiiviin igęm 'ahdas, kapea'. Jos uusia äännelakeja ehdotetaan, pitäisi niihin perustuvien rinnastusten olla hyvin uskottavia. Saarikiven lisäperustelu, että Petri Kallion mukaan vanha č olisi äännelaillisesti säilynyt etelävirossa, ei pidä paikkaansa. Kallio toteaa, että näin on tapahtunut etelävirossa vain sanansisäisesti $k$ :n edellä (Kallio 2007: 234). Mordvan verbin tongoms 'pistää, sujauttaa johonkin' (SSA III 326) takia hän joutuu kuitenkin lisäksi olettamaan rinnakkaismuotoa *tujke-. Voi tietenkin hypoteettisesti olettaa, että deskriptiivinen muutos $* t u->* c ̌ u$ - on erikseen tapahtunut myös komissa ja nimenomaan *u:n edellä; vrt. japanin $t s u-* t u$ :n tilalla. Unkarin verbiä dug 'tunkea; kätkeä' on myös rinnastettu epävarmana vastineena tähän pesyeeseen (Saarikivi 2007: 341; SSA III 326; UEW I 537-538). Lainaoletuksen kannalta se kyllä sopisi, koska germaaninen verbi on jo indoeurooppalaista perua (ieur. *twenk-: LIV 655; Hellquist 1252). Kreikassa sitä vastaa katoasteinen ieur. *twnk-yé- > kr. $\sigma \alpha ́ \tau \tau \omega$ 'ahtaa, tupata täyteen'. Unkarin verbi voisi olla erillinen laina.
} 


\section{8. ottaa}

Suomessa on vain joitakin verbejä, joilla on nykykielessä tarkalleen sama foneettinen rakenne kuin verbillä ottaa, siis rakenne (C)VttA-: tuskin muita kuin jättää, kattaa, kettää, mättää, pettää ja murteellinen asu kyttää 'kyteä; (Viron inkeri trans. 'polttaa mättäitä'), vielä suomen puolella oikeastaan esiintymätön syttää 'sytyttää' (inkeroinen, vatja). Näistä johdoksia ovat jättää (vrt. jäädä), kattaa (vrt. kansi : kante-), kettää (vrt. kesi : keden), kyttää (vrt. kyteä), syttää (vrt. syteä 'hakata' yms.) (Käänteissanakirja; SSA). Verbi mättää 'heittää, viskata, lappaa' on taas hyvin vanha slaavilainen laina, siinäkin on ollut konsonanttivartaloon liittynyt suffiksi *tä: *mättä- (Koivulehto 2006: 186-187; Lehtinen 2007: 239). Jäljellä on enää ottaa ja pettää. Olisi outoa, jos nämä kaksi olisivat morfologialtaan alun perin toisenlaisia eli pelkkiä perusvartaloita. Kun ei kumpaistakaan voida selittää johdoksiksi omaperäisistä lyhemmistä perusvartaloista, on niitä epäiltävä vanhoiksi lainoiksi, samanlaisiksi kuin verbi mättää. Molemmille löytyykin samanlainen lainaselitys (verbistä pettää ks. seuraava etymologia).

Verbi ottaa esiintyy kaikissa itämerensuomalaisissa kielissä. Etäsukukielissä sille taas ei ole pitäviä etymologisia vastineita. Sellaisiksi aikaisemmin esitetyt ovat kaikki äänteellisesti sopimattomia (perusteluista ks. tämän etymologian viimeistä kappaletta). Vatjan, viron ja liivin vastineet osoittavat, että verbissä on aikaisemmin ollut sananalkuinen *v-: va. vettā, vi. võtta, li. vett'. Perusmerkitys on kaikkialla sama 'ottaa'. Vatjassa, virossa ja liivissä on lisäksi vanha tekimen johdos, jota suomessa vastaisi *otin : ottimen, mutta jolla on hieman oudosti merkitys 'avain': va. vetī, vi. võti : gen. võtme, li. vet'im. 'Avaimen' semanttista suhdetta 'ottaa'-merkitykseen ei näytä kukaan käsitelleen (ks. esim. Länsimäki 1987: 15, 28, 41).

Verbin vartalo on siis ollut *votta-. Odottaisi tietenkin, että sananalkuinen $* v$ olisi eteläkantasuomessakin hävinnyt, kuten sen olisi pitänyt $o: n$ edellä hävitä. Edustus on siis poikkeuksellinen ja voi sekin viitata siihen, että verbi on vanha laina. Tämä ei kuitenkaan johda sen pitemmälle. Pitemmälle pääsemme, jos analysoimme verbin samalla tavalla kuin johdosverbin kattaa. Siitähän on äännelaillisesti jäänyt pois nasaali *-n-geminaatan -tt- edeltä. Kantavartalo on *kante- 'kansi', jonka konsonanttivartalo *kant- esiintyy johdoksessa: siis *kant-ta- on realisoitunut asuna *katta-.

Nyt löytyy indoeurooppalaiselta puolelta verbi, josta tuo selityksen edellyttämä *vont-elementti on voitu lainata. Verbi on samanlainen $o$-asteinen kausatiivinen ieur. -eye-suffiksilla johdettu verbi kuin verbille kostaa edellä esittämäni originaali. Kyseessä on germ. kausatiiviverbi *wand(i)ja- $>$ gootin wandjan, muinaisislannin venda, ruotsin vända, saksan wenden 'kääntää'. Tätä germaanista asua vastaa esigerm./ieur. kausatiiviasu *wond ${ }^{h}$-éye/o-. Sen kantaverbiä edustaa germ. *wenda- > *winda-> saksan winden 'vääntää'. Merkitysero näyttää suurelta, mutta on mielestäni kuitenkin riittävästi perusteltavissa.

Äänteellisesti etymologia on säännöllinen, se vain edellyttää lainautumista jo mainitusta esigermaanisesta asusta ${ }^{*}$ wond ${ }^{h}$-eye-. Vartalon muodostustapa on siis sama kuin tapauksessa *kosta-. Kun tässäkin suffiksi on korvattu omalla kausatiivi- 
suffiksilla -ta-, saadaan tulokseksi varhaiskantasuomen *vont-ta-, joka reaalistuu nasaalin putoamissäännön mukaisesti asuna *votta-. Semanttinen selitys lähtee siitä, että 'ottaminen' on alkujaan varmasti ollut myös 'väkivalloin ottamista, riistämistä', jopa 'luvattomasti ottamista, varastamista'. SKES (II 444) antaakin karjala-aunuksen ottoa/ottua-verbille myös merkitykset 'ottaa pois, kiinni; riistää, viedä; valloittaa; varastaa' (vrt. KKS IV 78-82), ja samat merkityssävyt ovat myös suomen verbillä. Tästä merkityssävystä päästään jo germaaniseen 'kääntämiseen'. Semanttisena paralleelina 'kääntää' > 'ottaa, varastaa' voi aluksi mainita suomen kääntää-verbin puhekielisen käytön merkityksessä 'varastaa, ryöstää': juopuneelta oli käännetty lompakko (NSU 46).

Tärkeämpää on, että germaanisista kielistä itsestäänkin löytyy kyseessä olevalle 'kääntää'-verbille käyttötapoja, joissa 'ottamisen, riistämisen, anastamisen' merkitys näkyy.

Muinaisnorjassa (Norjan vanhat lait) venda 'kääntää' on todettu myös merkityksessä "tilegne sig noget", 'omaksua, ottaa itselleen', sanonnassa venda e-t til sín, sananmukaisesti siis 'kääntää jotakin itselleen' (Fritzner III 907). Vanhemmassa tanskassa tämä käyttö näkyy selvästi: vende mm. "borttage, fjerne noget fra en, berøve en noget" eli 'ottaa pois joltakin, ryöstää joltakin jotakin' (ODS XXVI 1080-1081); vende til sig "skaffe sig (et gode) ved dygtighed, list ell. ran", eli 'hankkia itselleen (hyötyä, omaisuutta) taitavuudella, viekkaudella tai ryöstämällä': 'lader os slaae ham ihiel, og vende hans arv til os" = 'tappakaamme hänet ja ottakaamme hänen perintönsä itsellemme/haltuumme' (Matt. 21: 38; kreikkalaisessa alkutekstissä ja Vulgatassa ei ole käytetty 'kääntää'-verbiä, eli kyseessä ei ole käännöslaina niistä); Luther kääntää "an uns bringen", 'hankkikaamme itsellemme'.

Keskiyläsaksassa yhdysverbi er-wenden merkitsee mm. "(einem etwas) benehmen, entziehen", 'ottaa, ryöstää joltakin jotakin', samoin ent-wenden (Lexer I 699, 596); nykysaksassakin ent-wenden on 'ottaa joltakin jotakin luvattomasti, anastaa'. Tällainen käyttö on latinastakin tunnettu: lat. vertere 'kääntää', a-vertere 'kääntää pois' ja myös mm. 'varkain anastaa, kavaltaa'.

Selitykseni muotoutuu lyhyesti sanottuna seuraavanlaiseksi: ieur./esigerm. *wond ${ }^{h}$-éyelo-, jonka perusmerkitys oli 'kääntää' mutta tietyissä yhteyksissä jo tuolloin myös myöhemmin germaanisissa kielissä tavattavassa merkityksessä *'ottaa (väkisin), anastaa', lainautui (esi)kantasuomeen vartalona *vot-ta- ( $\leftarrow *$ vont-ta-). Jälkimmäinen merkitys voimistui tai kehittyi (esi)kantasuomessa.

Tämän etymologian valossa eteläkantasuomen 'avainta' merkitsevä johdos, *vottime- $>$ viron *võti : gen. võtme jne. saisi luontevan semanttisen tulkinnan. Lukkolaitteessa ja siihen kuuluvassa avaimessa on jotain, mitä käännetään: 'avain' motivoituisi siis semanttisesti tästä: 'väline, jolla käännetään'; vrt. Wiedemannin antamaa esimerkkilausetta võtmega lahti ja kinni käänama "ein Schloss auf und zuschließen", 'kääntää avaimella lukko auki ja kiinni' (Wiedemann 255, s.v. käänama) ja lisäksi esimerkkiä keeras võtmega luku lahti (EMSR II 694, s.v. lukk). Sana merkitsee muuten virossa murteittain myös 'lukko' (Wiedemann 1399). Lienee tosin tietymätöntä, miten vanhoja tällaiset vanhimmat kääntölaitteet (eli avaimet) ovat. Mutta 
ainakin ne ovat niin vanhoja kuin niitä tarkoittavat sanat, ja varmaan aivan vanhimmissakin sulkemis- ja avaamislaitteissa on ollut jonkinlainen käännettävä osa (vrt. myös saksan Wendeschlüssel 'kääntöavain').

Kommentoin lopuksi ottaa-verbiin epävarmoina vastineina esitettyjä etäsukukielten verbejä (SSA). Saamesta on tällaiseksi oletettu verbiä vuohttit 'tavata tai löytää (vars.) eläimen jäljet, jäljittää; olla havaitsevinaan, tuntea' (SSS 480). Verbin vokaali ei kuitenkaan sovi yhteen itämerensuomen verbin kanssa, koska saamen verbi edellyttää ensi tavuun joko alkuperäistä lyhyttä *a:ta tai pitkää $* \bar{o}$ :ta. Jälkimmäinen vaihtoehto on jo fonotaktisestikin epätodennäköinen, ainakin perusvartalona. Saamen verbi on sitä paitsi semanttisestikin kovin kaukana itämerensuomen verbistä. Pitkä *ō kyllä näytäisi sopivan komin verbiin vetni (vartalo vet-) 'tavoittaa; ajaa takaa' (ks. Itkonen 1953: 324): vrt. esim. vuolla : vuolen $\sim$ komin vel-al-; rinnastusta ei kuitenkaan mainitse Erkki Itkonen (1953) eikä Pekka Sammallahti (1988). Jos rinnastus olisi oikea, verbissä olisi siis sm.-perm. *-tt-, joka lienee vanhoissa perusvartaloissa peräti harvinainen geminaatta (vrt. Sammallahti 1998: 199; saamesta esimerkkinä juuri vuohttit). Komin verbi votni (vartalo vot-) 'kerätä, poimia (sieniä, marjoja)', jonka Pekka Sammallahti (1988: 554) on vielä liittänyt itämerensuomen verbiin, ei myöskään voi olla yhteisen lähtömuodon kautta rinnastettavissa, koska itämerensuomen $o$ :ta ei voi vastata komin $o$ (vaan $u$ ), kuten Sammallahti (1988: 524-531) itse on osoittanut; vokaalin takia jo aikaisemmin Erkki Itkonen (1956: 73) on epäillyt tätä yhdistämistä. Sen sijaan ei mikään estäne ajattelemasta, että komin verbi on vanha laina (varhais)kantasuomesta, jolloin *o olisi säilynyt. Onhan komiin tulleita vanhoja itämerensuomalaisia lainoja muitakin. Sitä paitsi vanhoissa indoeurooppalaiselta puolelta tulleissa lainoissa voi olla muutenkin komin $o$ vastaamassa itämerensuomen *o:ta: vrt. kota komi ko(la). Mansissa on lisäksi semanttisesti komin verbiä vastaava verbi, jota myös on ajateltu sen vastineeksi (Itkonen 1988: 328; Itkonen on kuitenkin liittänyt tähän rinnastukseen kysymysmerkin). Sammallahti ei mainitse tätä rinnastusta. $^{14}$

\section{9. pettää}

Suomen verbillä pettää 'to deceive' on vastineet kaikissa itämerensuomalaisissa kielissä (SSA II 345): ink. pettä 'pettää', ka. petteä 'pettää, valehdella: jättää, pistää syrjään; olla epäluotetteva, kestämätön', ly. petties 'vahingossa, ehdyksessä', ve. pettas 'erehtyä', va. pettä 'pettää', li. piett' 'pettää, valehdella'. Virosta on verbille kirjattu laajempi merkityskirjo: petma : petta "betrügen, heimlich entwenden, verführen, verlocken" eli 'pettää, ottaa salaa, vietellä, houkutella', pettis teda metsa "er lockte ihn in den Wald", koera leivaga p. "einen Hund mit Brot an sich locken", 'houkutella koiraa luokseen leivällä', ära petma "ablocken, abbetrügen, verblenden, bestechen, verbergen, verstecken" eli 'houkutella pois, sokaista, lumota, piilottaa' (Wiedemann

\footnotetext{
14 Jos rinnastus siitä huolimatta osuisi oikeaan, olisi verbin pitänyt lainautua indoeuroopasta suomalaisugrilaiselle puolelle jo varsin varhain. Tai vaihtoehtoisesti: voisiko mansin verbi olla lainaa komista?
} 
804). Etäsukukielissä sillä ei ole vastineita. Tämäkään verbi ei ole voinut syntyä itämerensuomeen tyhjästä, eikä se rakenteensakaan puolesta sovi "deskriptiiviseksi" muodosteeksi. Selitykseksi jää siis, että se on vanha laina. Se selittyykin samalla tavalla kuin äsken käsitelty verbi ottaa, tällä kertaa vanhaksi balttilaisperäiseksi lainaksi.

Liettuassa on verbi (inf.) spésti : (prees. 3. p.) spéndžia, jolla on monenlaisia vastineita saksaksi, perusmerkityksenä on kuitenkin 'asettaa ansoja' (alun perin: jännittämällä ansalankaa): "spannen; mittels Spannens stellen, legen (z. B. Fallen); (Wild usw.) mit Fallen legen, stellen; (trans.) Fallen stellen; Fallstricke legen, auf etw. absehen, etwas erstreben" (Fraenkel II 865); kilpas, pinkles spésti "Schlingen, Fallstricke legen", kám kilpas - - spésti "jemandem eine Falle stellen, (übertr.) gegen jemand Ränke schmieden", (intrans.) "Fallen stellen, Fallstricke legen"; kàs kitám spéndžia, tàs pàts ỉkliūva "wer einem anderen eine Grube gräbt, fällt selbst hinein" (Niedermann IV 52). Verbi esiintyy joko transitiivisena, jolloin objektina on joko 'tavoiteltu riistaeläin' (Niedemann ibid.) tai 'ansa, paula, juoni', tai myös intransitiivisena, jolloin juonittelun kohde ilmaistaan datiivilla.

Liettuan verbi on ns. -ia-verbi, eli sen preesensvartalo muodostuu suffiksilla *-ia-: (prees. 3. p.) spéndžia < baltt. *spendia- (ieur. suffiksi on *-ye-/-yo-). Perusvartalo *spend- näkyy suoraan preteritissä: (3. p.) spéndé, samoin infinitiivissä spésti; kun siihen on liittynyt infinitiivin suffiksi *-ti-, on tuloksena ollut äännelaillisesti yhtymä $*_{\text {-st- }}\left(<\right.$ ieur. ${ }^{*}$-tst- $\leftarrow *_{-}-d$-t-). Yhtymä *-tst- on rekonstruoitava siis jo indoeurooppa-

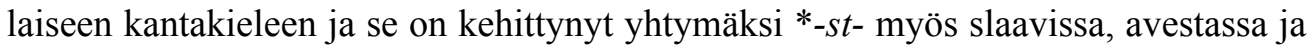
muinaisiirissä, kun taas germaanissa ja latinassa on *-ss- (ks. esim. Mayrhofer 1986: 110). - Baltin -st-:n edellä sekvenssi *-en- on muuttunut pitkäksi nasaalivokaaliksi (nykyliettuassa ei enää nasaalisuus äänny).

Tämä balttilainen verbi esiintyy myös latviassa, mutta on siellä kehittynyt merkitykseen 'painaa, puristaa, pakottaa, vangita': inf. spiêst "drücken, pressen, wingen, nötigen, fangen" (Fraenkel II 865). Tämä merkitys on selvästi sekundaari, koska balttilais-indoeurooppalainen semanttinen tausta on 'jännittää, pingottaa' yms. (vrt. saksan spannen, ruotsin spänna; ks. esim. Fraenkel ibid. ja LIV 578).

Itämerensuomen verbi selittyy siis jälleen siten, että "suoraa" lainausta baltin verbin perusvartalosta *spend- edustaa itämerensuomen konsonanttivartalo *pent-, johon on liitetty omaperäinen verbaalisuffiksi *-tä-: *pent-tä-. Foneettinen reaalistuma tästä on * pettä-. ${ }^{15}$

\footnotetext{
15 Sama vartalotyyppi (vain intonaatio on toinen) kuin verbillä spésti on baltin verbillä (liett.) kęsti (baltt. perusvartalo *kent-, preesensvartalo, 3. p. *kent-ja) 'kärsiä, kestää', jonka (kanta)balttilaisesta asusta olen juontanut suomen verbin kestää (Koivulehto 1989: 176). Baltin verbin mukauttaminen itämerensuomeen on johtanut siis tässä erilaiseen substituutioon. Selitys tähän on nähdäkseni siinä, että **ket-tä- olisi johtanut häiritsevään homonymiaan verbin *ket-tä- 'nylkeä nahka' kanssa. Sen välttämiseksi on verbi substituoitu infinitiivin konsonanttiyhtymään tukeutuen: baltt. *-st-. Ei liene syytä ajatella, että suomen $-s$ - palautuisi tässä vanhempaan ${ }^{*}-\dot{c}^{\prime}$-hen, joka heijastaisi baltin myöhempää affrikaattaa preesensissä.
} 
Semanttisesti baltin ja itämerensuomen verbit ovat lähellä toisiaan. Onhan baltin 'ansan, paulan asettaminen; "kuopan kaivaminen", juonien punominen (jonkun pään menoksi)' toki '(ihmisen tai riistaeläimen) pettämistä'. Liettuan ja suomen verbien semanttinen ero on lähinnä vain se, että edellinen jättää avoimeksi, onnistuuko juoni, kun sen sijaan suomen verbi antaa sen kuvan, että juoni on onnistunut. Toisaalta ero on jopa pienempikin: vrt. erityisesti Wiedemannin viron verbille antamaa merkityssävyä "verführen, verlocken", 'vietellä, houkutella' ja toisaalta vaikka liettuan edellä siteerattua sananlaskua kàs kitám spéndžia, tàs pàts įkliūva 'joka toiselle ansaa asettaa/punoo ("kuoppaa kaivaa"), se sinne itse joutuu/putoaa'.

Semantiikan suhteen verrattakoon vielä esim. lat. decipere 'saada satimeen, pettää, peijata', josta johdos decipula 'ansa, sadin'; kr. $\delta o ́ \lambda o \varsigma$ 'syötti, houkutuskeino; petos, juoni' lat. dolus 'juoni, petos'; ruotsin list 'viekkaus, kavaluus; petos, juoni'; keskialasaksan lūren "lauern, warten; betrügen, hintergehen" (Schiller \& Lübben II 170) eli 'väijyä; pettää, petkuttaa', josta ruotsiin lainattu lura 'väijyä; pettää, petkuttaa' (Hellquist 597); engl. wile 'juoni, kepponen' = engl. murt. wile 'a set of five snares to a hoop floating on the water for catching wild ducks" (Wright 1905: 492).

\section{0. *taistaa, taisto, taistella}

Verbi taistella näyttää esiintyvän vain suomessa (SSA III 255-256). SSA mainitsee, että verbiä taistella 'kämpfen' on selitetty johdokseksi vartalosta taka- 'Hinter-' (taka-na, taka-puoli jne.). Semanttisesti tämä selitys on aivan epätodennäköinen, jopa mahdoton. Kantavartalo on kyllä *taka-, mutta se on lainaa germaanista: $\leftarrow$ germ./ kantaskand. *taka- 'ottaa, tarttua kiinni', myös nominina *taka- 'ote' yms. Verbin ja nominin perusmerkityksestä juontuu skandinaavisissa kielissä monia merkityssävyjä, kuten myös 'otella, painia, taistella', 'ottelu, paini, taistelu': muinaisruotsi taka i mot 'tehdä vastarintaa' ("göra motstånd"), (refl.) takas 'käydä toistensa kimppuun' ("gå på med hvarandra, hållas"), tak 'ote; ote painissa tai taistelussa' ("tag i brottning el. kamp"; Söderwall 614, 609, Supplement II 870), gotlannin murre (refl.) tagas (*takas) "brottas med armkast eller krage-tak, med rygg-kast, med byxe-kast" (Gustavson et al. II 1065); nykyruotsi (refl.) tagas 'tapella, riidellä' (SAOB XXXIII T 128); muinaisislanti taka i mót 'tehdä vastarintaa, asettua vastarintaan' ('gjøre Modstand, sætte sig til Modværge", Fritzner III 667), norjan murt. tak 'ote; ottelu, kahakka' ('tak, grep; kamp, dyst", Torp 768).

taistella, taistelee on iteratiivinen johdos lyhyemmästä kannasta *taistaa (vartalo *taista-). Kyseessä on siis suffiksilla -ista- muodostettu lainaverbi, samanlainen kuin kallistaa, loistaa, maistaa jne. Lyhyempää kantaa ei näytä enää jääneen kieleen, sitä edustaa kuitenkin siitä johdettu nomini taisto: vrt. loistaa : loisto. *taista-/taisteleedustaa heikkoasteista asua: *tayista- $(<*$ takista-), kuten esim. maistaa jne. Heikon asteen $*-\gamma$ - on äännelaillisesti kadonnut.

Skandinaavisen kannan semantiikalle tarjoaa tarkan paralleelin ottaa : otella. Tässäkin on siis suomessa iteratiivijohdos. 
On kai mahdotonta tietää, onko suomen verbin kantana skandinaavinen verbi vai substantiivi. Joka tapauksessa laina on saatu asusta *taka-. Lainautumisaikaakin on vaikea määritellä. Varhaiseen aikaan voisi kyllä viitata se, että germ.-skand. *-kon suomessa korvattu vain yksinkertaisella klusiililla *-k-. Toisaalta on huomattava, että skandinaavisen verbinkin klusiili on tässä myöhemmin osittain heikentynyt (vrt. ruotsin taga). Verrattakoon myös lainaa lakata : lakkaan, jonka rinnalla esiintyy myös infinitiivi laata ja partisiippi laannut.

Samaan lainakantaan kuvittelisi helposti kuuluvan myös murt. takistaa 'tarttua kiinni, takertua' ja takistella 'tarttu(ill)a kiinni, takellella; vastustella' (SSA III 258), jossa nyt siis todella näkyisi geminaatta. Rinnalla on takertua 'tarttua kiinni'. Virossa on verbi takistada merkityksessä 'kiinnittää, painaa kiinni; pitää kiinni; estää, ehkäistä; pysähtyä, pysyä kiinni; kompastua; änkyttää' (SSA ibidem). Pesye on laaja: vrt. myös takellella ja takkala keli 'tarttuva lumikeli', jopa ehkä takku 'sotkeentunut tukka'. Kyseessä on ainakin osittain deskriptiivistynyt sanue, jonka juuria on enää vaikea kaivaa esiin. Voi tietenkin ajatella, että germaanisperäinen *taka- on jo varhain kehittänyt rinnalleen tällaisia deskriptiivistyneitä rönsyjä, lainathan helposti deskriptiivistyvät. Myös kasvinnimellä takiainen 'Klette' voisi olla kansanetymologista vaikutusta (ja päinvastoin: vrt. murt. takkiainen, SSA ibidem): takiainen tarttuu kiinni ja tähän perustuu etymologisesti myös saksan Klette. Suomen kasvinnimi on kuitenkin tunnetusti balttilainen laina.

\section{Lähteet}

Aasen = Aasen, Ivar 1918: Norsk Ordbog med dansk Forklaring. Fjerde uforandrede Udgave. Kristiania: Alb. Cammermeyers Forlag.

AhdW = Karg-Gasterstädt, Elisabeth \& Theodor Frings \& Rudolf Grosse (toim.) 1968-: Althochdeutsches Wörterbuch I-. Berlin: Akademie Verlag.

Ásgeir = Ásgeir Blöndal Magnússon 1989: Íslensk orðsifjabók. Reykjavík: Orðabók Háskólans.

Bartens, Raija 1999: Mordvalaiskielten rakenne ja kehitys. Suomalais-Ugrilaisen Seuran toimituksia 232. Helsinki: Suomalais-Ugrilainen Seura.

Bosworth $=$ Bosworth, Joseph \& Toller, T. Northcote (edited and enlarged) 1898: An Anglosaxon Dictionary. Oxford: Oxford University Press.

Carpelan, Christian \& Parpola, Asko 2001: Emergence, Contacts and Dipersal of Proto-IndoEuropean, Proto-Uralic and Proto-Aryan in Archaeological Perspective. - Christian Carpelan, Asko Parpola \& Petteri Koskikallio (toim.), Early Contacts between Uralic and Indo-European: Linguistic and Archaeological Considerations. Suomalais-Ugrilaisen Seuran Toimituksia 242. Helsinki: Suomalais-Ugrilainen Seura. 55-150.

Eurén = Eurén, G. E. 1860: Finsk-Swensk Ordbok / Suomalais-Ruotsalainen Sanakirja. Hämeenlinna: G. E. Eurén.

EWAia = Mayrhofer, Manfred 1986-1997: Etymologisches Wörterbuch des Altindoarischen I-II. Heidelberg: Carl Winter.

Fraenkel = Fraenkel, Ernst 1962-1965: Litauisches etymologisches Wörterbuch I-II. Heidelberg - Göttingen: Carl Winter - Vandenhoeck \& Ruprecht. 
Fritzner = Fritzner, Johan 1973: Ordbog over Det gamle norske Sprog I-III. [4. painos.] Oslo - Bergen - Tromsø: Universitetsforlaget.

Ganander = Ganander, Christfrid 1937-1940: Nytt Finskt Lexicon I-III. Porvoo: Werner Söderström. [Näköispainos käsikirjoituksesta vuosilta 1786-1787.]

Gustavson et al. = Gustavson, Herbert (et al., toim.) 1918-1945: Gotländsk orbok på grundval av C. och P. A. Säves samlingar I-II. Uppsala: A.-B. Lundequistska bokhandeln.

Hakulinen, Lauri 1940: Kostea ja kostua. - Virittäjä 44: 43-47.

Hakulinen, Lauri 2000: Suomen kielen rakenne ja kehitys. 5., muuttamaton painos. Vantaa: Helsingin yliopiston suomen kielen laitos.

IEW = Pokorny, Julius 1959: Indogermanisches etymologisches Wörterbuch. Bern: Francke Verlag.

ILW = Inarilappisches Wörterbuch. Herausgegeben von Erkki Itkonen unter Mitarbeit von Raija Bartens und Lea Laitinen. Lexica Societatis Fenno-Ugricae XX. Helsinki: Suomalais-Ugrilainen Seura 1986-1991.

Itkonen, Erkki 1953: Zur Geschichte des Vokalismus der ersten Silbe im Tscheremissischen und in den permischen Sprachen. - Finnisch-Ugrische Forschungen 31: 149-345.

Itkonen, Erkki 1956: Etymologisches Wörterbuch der uralischen Sprachen (Besprechung von Björn Collinder, Fenno-Ugric Vocabulary). - Ural-Altaische Jahrbücher 28: 56-80.

Itkonen, Erkki 1988: Vokaaliston kysymyksiä. - Virittäjä 92: 325-330.

Janhunen, Juha 1981: Uralilaisen kantakielen sanastosta. - Suomalais-Ugrilaisen Seuran Aikakauskirja 77: 219-274.

Janhunen, Juha 2007: The Primary Laryngeal in Uralic and beyond. - Jussi Ylikoski \& Ante Aikio (toim.), Sámit, sánit, sátnehámit. Riepmočála Pekka Sammallahtii miessemánu 21. beaivve 2007. Suomalais-Ugrilaisen Seuran Toimituksia 253. Helsinki: SuomalaisUgrilainen Seura. 203-227.

Joki, Aulis J. 1973: Uralier und Indogermanen. Die ältesten Berührungen zwischen den uralischen und indogermanischen Sprachen. Suomalais-Ugrilaisen Seuran toimituksia 151. Helsinki: Suomalais-Ugrilainen Seura.

Juslenius, Daniel 1745: Suomalaisen Sana-Lugun Coetus / Fennici Lexici Tentamen. Stockholm: Lars Salvius.

Kallio, Petri 2007: Kantasuomen konsonanttihistoriaa. - Jussi Ylikoski \& Ante Aikio (toim.), Sámit, sánit, sátnehámit. Riepmočála Pekka Sammallahtii miessemánu 21. beaivve 2007. Suomalais-Ugrilaisen Seuran Toimituksia 253. Helsinki: Suomalais-Ugrilainen Seura. 229-249.

Kallio, Petri \& Koivulehto, Jorma (tulossa): On the Finnic Hydrogeographical Terminology. FS NN.

KKS = Virtaranta, Pertti \& Raija Koponen (päätoim.) 1968-2005: Karjalan kielen sanakirja I-VI. Lexica Societatis Fenno-Ugricae XVI, Kotimaisten kielten tutkimuskeskuksen julkaisuja 25. Helsinki: Suomalais-Ugrilainen Seura - Kotimaisten kielten tutkimuskeskus.

Koivulehto, Jorma 1981: Reflexe des germ. /e $1 /$ im Finnischen und die Datierung der germanisch-finnischen Lehnbeziehungen. - Beiträge zur Geschichte der deutschen Sprache und Literatur (Tübingen) 103: 167-203, 333-376.

Koivulehto, Jorma 1989: Ehkä ja ehto, yskä ja ystävä. - Suomalais-Ugrilaisen Seuran Aikakauskirja 82: 171-192. 
Koivulehto, Jorma 1991: Uralische Evidenz für die Laryngaltheorie. Sitzungsberichte der Österreichischen Akademie der Wissenschaften, Philosophisch-historische Klasse 566. Wien: Verlag der Akademie.

Koivulehto, Jorma 1999: Varhaiset indoeurooppalaiskontaktit: aika ja paikka lainasanojen valossa. - Paul Fogelberg (toim.), Pohjan poluilla. Suomalaisten juuret nykytutkimuksen mukaan. Bidrag till kännedom av Finlands natur och folk 153. Helsinki: Finska Vetenskaps-Societeten - Suomen Tiedeseura. 207-236.

Koivulehto, Jorma 2000: Finno-Ugric Reflexes of North-West Indo-European and Early Stages of Indo-Iranian. - Karlene Jones-Bley, Martin E. Huld \& Angela Della Volpe (toim.), Proceedings of the Eleventh Annual UCLA Indo-European Conference. Journal of Indo-European Studies. Monograph Series 35. Washington, D.C.: Institute for the Study of Man. 21-43.

Koivulehto, Jorma 2001a: The Earliest Contacts between Indo-European and Uralic Speakers in the Light of Lexical Loans. - Christian Carpelan, Asko Parpola \& Petteri Koskikallio (toim.), Early Contacts between Uralic and Indo-European: Linguistic and Archaeological Considerations. Suomalais-Ugrilaisen Seuran Toimituksia 242. Helsinki: Suomalais-Ugrilainen Seura. 235-263.

Koivulehto, Jorma 2001b: Zum frühen iranischen und indoiranischen lexikalischen Einfluss auf das Finnisch-Ugrische. - Klaus Karttunen \& Petteri Koskikallio (toim.), Vidyārnavavandanam. Essays in Honour of Asko Parpola. Studia Orientalia 94. Helsinki: Finnish Oriental Society. 359-378.

Koivulehto Jorma 2006: Wie alt sind die Kontakte zwischen Finnisch-Ugrisch und BaltoSlavisch? - Juhani Nuorluoto (toim.), The Slavicization of the Russian North. Mechanisms and Chronology. Slavica Helsingiensia 27. Helsinki. 179-196.

Koivulehto, Jorma 2007: Saamen ja suomen 'poro'. - Jussi Ylikoski \& Ante Aikio (toim.), Sámit, sánit, sátnehámit. Riepmočála Pekka Sammallahtii miessemánu 21. beaivve 2007. Suomalais-Ugrilaisen Seuran Toimituksia 253. Helsinki: Suomalais-Ugrilainen Seura. 252-258.

Koivulehto, Jorma \& Vennemann, Theo 1996: Der finnische Stufenwechsel und das Vernersche Gesetz. - Beiträge zur Geschichte der deutschen Sprache und Literatur 118: $163-162$.

Käänteissanakirja = Tuomi, Tuomo (koost.) 1980: Suomen kielen käänteissanakirja. Helsinki: Suomalaisen Kirjallisuuden Seura.

Lehtinen, Tapani 2007: Kielen vuosituhannet. Suomen kielen kehitys kantauralista varhaissuomeen. Tietolipas 215. Helsinki: Suomalaisen Kirjallisuuden Seura.

Lexer = Lexer, Matthias 1872-1878: Mittelhochdeutsches Handwörterbuch I-III. Leipzig: Verlag von S. Hirzel.

LIV = Lexikon der indogermanischen Verben. Die Wurzeln und ihre Primärstammbildungen . Unter der Leitung von Helmut Rix und der Mitarbeit vieler anderer bearbeitet von Martin Kümmel et al. Wiesbaden: Ludwig Reichert Verlag 1998.

LiW = Kettunen, Lauri 1938: Livisches Wörterbuch. Lexica Societatis Fenno-Ugricae V. Helsinki: Suomalais-Ugrilainen Seura.

Lubotsky, Alexander 2001: Reflexes of Proto-Indo-European *sk in Indo-Iranian. - Incontri Linguistici 24: 24-57.

Länsimäki, Maija 1987: Suomen verbikantaiset in : ime -johdokset. Suomalaisen Kirjallisuuden Seuran Toimituksia 469. Helsinki: Suomalaisen Kirjallisuuden Seura. 
Lönnrot = Lönnrot, Elias 1874-1880: Suomalais-Ruotsalainen Sanakirja I-II ja lisävihko (toim. A. H. Kallio) 1886. Kolmas painos 1958. Helsinki: Werner Söderström.

M-W = Monier-Williams, Monier 1899: A Sanskrit-English Dictionary. Oxford: The Clarendon Press.

Mayrhofer, Manfred 1986: Lautlehre (Segmentale Phonologie des Indogermanischen). Manfred Mayrhofer (toim.), Indogermanische Grammatik I, 2. Halbband. Heidelberg: Carl Winter.

Mayrhofer, Manfred 1989: Vorgeschichte der iranischen Sprachen; Uriranisch. - Rüdiger Schmitt (toim.), Compendium linguarum Iranicarum. Wiesbaden: Ludwig Reicher Verlag. 4-24.

NES = Häkkinen, Kaisa 2004: Nykysuomen etymologinen sanakirja. Juva: WS Bookwell Oy.

Niedermann $=$ Niedermann, Max \& Senn, Alfred \& Brender, Franz 1932-1968: Wörterbuch der litauischen Schriftsprache. Litauisch-Deutsch. I-V. Heidelberg: Carl Winter.

Noreen, Adolf 1903: Altisländische und Altnorwegische Grammatik. Dritte vollständig umgearbeitete Auflage. Halle: Max Niemeyer.

NSU $=$ Nykysuomen sanakirja. Uudissanat. Toimittanut Kotimaisten kielten tutkimuskeskuksen kielitoimisto. Helsinki: Werner Söderström 1979.

ODS = Ordbog over det Danske Sprog I-XXVII. København: Gyldendalske Boghandel 1919-1954.

OED = The Oxford English Dictionary I-XX. Second Edition. Oxford: Clarendon Press 1989.

Parpola, Asko 1998: Aryan Languages, Archaeological Cultures, and Sinkiang: Where Did Pro-Iranian Come into Being, and How Did It Spread? - Victor H. Mair (toim.), The Bronze Age and Iron Age Peoples of Eastern Central Asia, I. The Journal of IndoEuropean Studies Monograph 26, 1. Washington, D.C.: Institute for the Study of Man. 114-147.

Parpola $=$ Parpola, Asko (toim.) 2005: Intian kulttuuri. [Kirjoittajat: Jaakko Hämeen-Anttila, Klaus Karttunen, Petteri Koskikallio, Asko Parpola, Marjatta Parpola \& Henri Schildt.] Helsinki: Otava.

PDW = Junker, Heinrich F. J \& Bozorg, Alavi 1965: Persisch-deutsches Wörterbuch. Leipzig: VEB Verlag Enzyklopädie.

$\mathrm{PED}=$ A Comprehensive Persian-English Dictionary. Revised, enlarged, and entirely reconstructed by F. Steingass. Beirut: Librarie du Liban 1892. [Reprinted 1975.]

Rédei, Károly 1986: Zu den indogermanisch-uralischen Sprachkontakten. Sitzungsberichte der Österreichischen Akademie der Wissenschaften, Philosophisch-historische Klasse 468. Wien: Verlag der Akademie.

Renvall = Renvall, Gustav 1826: Suomalainen Sana-Kirja I-II. Turku: Typis Fraenckellianis.

Saarikivi, Janne 2007: Uusia vanhoja sanoja. - Jussi Ylikoski \& Ante Aikio (toim.), Sámit, sánit, sátnehámit. Riepmoćála Pekka Sammallahtii miessemánu 21. beaivve 2007. Suomalais-Ugrilaisen Seuran Toimituksia 253. Helsinki: Suomalais-Ugrilainen Seura. 325-347.

Sammallahti, Pekka 1988: Historical Phonology of the Uralic Languages, with special Reference to Samoyed, Ugric, and Permic. - Denis Sinor (toim.), The Uralic Languages. Description, History and Foreign Influences. Leiden: E. J. Brill. 478-554. 
Sammallahti, Pekka 1998: The Saami Languages. An Introduction. Kárášjohka: Davvi Girji.

$\mathrm{SAOB}=$ Ordbok öfver svenska språket utgifven af Svenska Akademien I-. Lund: Berlingska tryckeriet 1898 -.

Schiller \& Lübben $=$ Schiller, Karl \& Lübben, August 1875-1880: Mittelniederdeutsches Wörterbuch I-V. Bremen: Verlag von J. Kühtmann's Buchhandlung.

Schrijver, Peter 1991: The Reflexes of the Proto-Indo-European Laryngeals in Latin. Amsterdam - Atlanta, GA: Rodopi.

SKES = Toivonen, Y. H. \& Itkonen, Erkki \& Joki, Aulis J. \& Peltola, Reino 1955-1981: Suomen kielen etymologinen sanakirja I-VI (VII: Sanahakemisto, koostaneet Satu Tanner \& Marita Cronstedt). Lexica Societatis Fenno-Ugricae XII. Helsinki: Suomalais-Ugrilainen Seura.

SMS = Tuomi, Tuomo \& Matti Vilppula \& Ulla Takala (päätoim.) 1985-: Suomen murteiden sanakirja I-. Kotimaisten kielen tutkimuskeskuksen julkaisuja 36. Helsinki: Kotimaisten kielten tutkimuskeskus - Valtion painatuskeskus.

SSA = Itkonen, Erkki \& Ulla-Maija Kulonen (toim.) 1992-2000: Suomen sanojen alkuperä. Etymologinen sanakirja I-III. Suomalaisen Kirjallisuuden Seuran Toimituksia 556, Kotimaisten kielten tutkimuskeskuksen julkaisuja 62. Helsinki: Kotimaisten kielten tutkimuskeskus - Suomalaisen Kirjallisuuden Seura.

SSS = Sammallahti, Pekka 1989: Sámi-suoma sátnegirji / Saamelais-suomalainen sanakirja. Ohcejohka: Jorgaleaddji.

Söderwall $=$ Söderwall, K. F. 1884-1918: Ordbok öfver svenska medeltids-språket I-II. Lund: Berlingska boktryckeriet. Supplement. Lund: Berlingska boktryckeriet 1953-1973.

Toller $=$ Toller, T. Northcote 1921: An Anglo-Saxon Dictionary, Supplement . Oxford: Oxford University Press.

Torp = Torp, Alf 1919: Nynorsk etymologisk ordbok. Kristiania: H. Aschehoug.

Turner = Turner, R. L. 1966: A Comparative Dictionary of the Indo-Aryan Languages. London: Oxford University Press.

UEW = Rédei, Karoly 1988-1991: Uralisches etymologisches Wörterbuch I-III. Wiesbaden: Otto Harrassowitz.

Vennemann, Theo 1984: Hochgermanisch und Niedergermanisch: Die Verzweigungstheorie der germanisch-deutschen Lautverschiebungen. - Beiträge zur Geschichte der deutschen Sprache und Literatur (Tübingen) 106: 1-45.

Wiedemann = Wiedemann, Ferdinand Johann 1973: Eesti-saksa sõnaraamat / Estnischdeutsches Wörterbuch. Neljas, muutmata trükk teisest, Jakob Hurda redigeeritud väljaandest. Tallinn: Valgus.

VKS = Vanhan kirjasuomen sanakirja $\mathrm{I}-$. Kotimaisten kielten tutkimuskeskuksen julkaisuja 39. Helsinki: Kotimaisten kielten tutkimuskeskus 1985-.

Vries $=$ Vries, Jan de 1961: Altnordisches etymologiches Wörterbuch. Leiden: Brill.

Wright, Joseph 1905: The English Dialect Dictionary VI. London: Henry Frowde \& Oxford: 116 High Street \& New York: P. G. P. Putman's Sons.

Jorma Koivulehto <jorma.koivulehto@helsinki.fi>

Mariankatu 11

PL 11

00014 Helsingin yliopisto 